\title{
Formulation and characterization of blended alkali-activated materials based on flash-calcined metakaolin, fly ash and GGBS
}

\author{
Gabriel Samson ${ }^{1}$, Martin $\mathrm{Cyr}^{1}$, Xiao Xiao $\mathrm{Gao}^{2}$ \\ ${ }^{1}$ LMDC, INSAT/UPS Génie Civil, 135 Avenue de Rangueil, 31077 Toulouse cedex 04 France. \\ ${ }^{2}$ ECOCEM, 3rd Floor Port view House, Grand Canal Docks, Dublin 4, Ireland
}

To cite this article: G. Samson, M. Cyr, X.X. Gao, Formulation and characterization of blended alkali-activated materials based on flash-calcined metakaolin, fly ash and GGBS, Constr. Build. Mater. 144 (2017) 50-64. doi:10.1016/j.conbuildmat.2017.03.160.

\section{Highlights}

- AAMs initial setting time, shrinkage, mass loss, compressive strength were studied.

- Low activation leads to high drying shrinkage because of important mass loss.

- Very low shrinkage values were found for MK-GGBS compared to the other AAMs.

- High early strength compressive strength was observed for MK-GGBS blends.

\section{Graphical abstract}

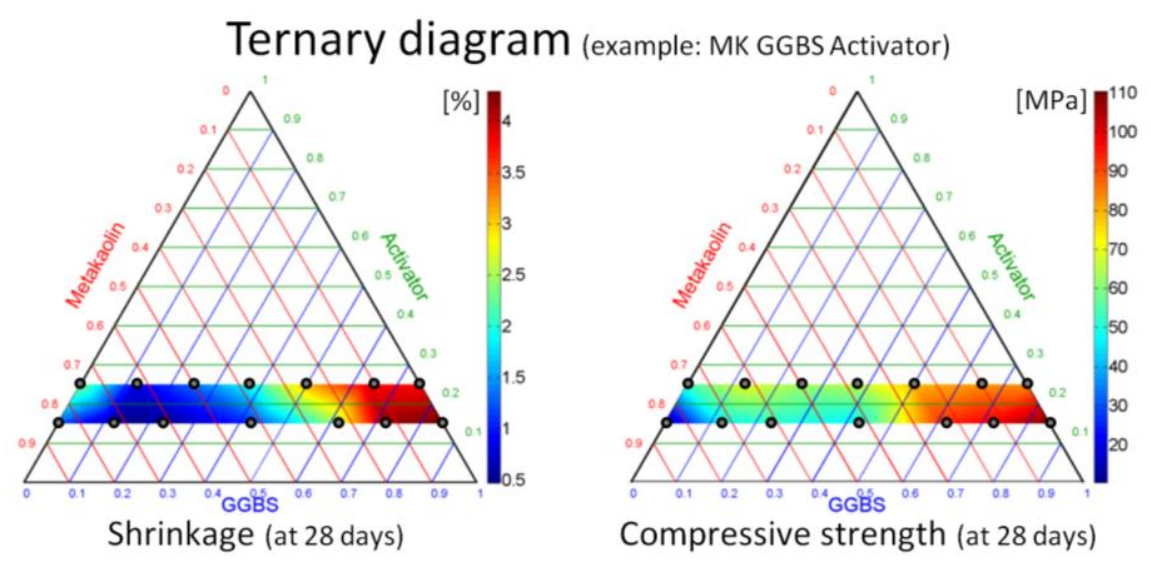




\begin{abstract}
Studies performed on alkali-activated materials (AAMs) in recent years reveal that they could be an alternative to ordinary Portland cement (OPC). The main precursors used are flash-calcined metakaolin (MK), fly ash (FA), and ground granulated blast furnace slag (GGBS). Usually, only one precursor is used to produce an AAM. The aims of this study were to measure and compare the performances of pure (one precursor) and blended AAMs (two precursors). Alkaline solution is added to activate the precursors and the influence of the activation rate was also investigated by changing the activator amount ( $15 \%$ and $25 \%$ of alkaline solution dry extract). Twenty-six different mixes were studied and are presented in a ternary representation. The mixtures were characterized in the fresh state (initial setting time) and the main properties useful for building applications (shrinkage, mass loss, and compressive strength) were recorded and analysed. In contrast to the situation in OPC systems, shrinkage and mass loss in AAMs were not directly correlated. The high shrinkage values observed for pure MK AAMs and pure GGBS AAMs were significantly reduced when they were associated in appropriate proportions. The association of MK and GGBS also proved very interesting regarding early age compressive strength.
\end{abstract}

Keywords: Alkali-activated material (AAM), metakaolin (MK), fly ash (FA), ground granulated blast furnace slag (GGBS), compressive strength, shrinkage 


\section{Introduction}

The building sector is faced with the gradual exhaustion of natural resources and/or increasing difficulty in accessing them. The worldwide demand for ordinary Portland cement (OPC) has grown to around 4.2 Gt/year (in 2014 [1]). The development of AAMs has aroused the interest of the scientific community in recent decades because these materials appear to provide an effective alternative to OPC cement [2] and because most of them are produced with industrial by-products. AAMs are not intrinsically or fundamentally 'low- $\mathrm{CO}_{2}$ '. However, if mix design and raw materials selection are carried out with a view towards optimisation of environmental performance, the outcomes can result in very significant savings [3]. They can exhibit comparable or better mechanical properties [4] and thermal stability [5,6] than OPC cements and they can also be employed for thermal insulation [7], wall panelling and fire resistant coating $[8,9]$. One of the major newer applications is in the storage of waste, such as toxic or nuclear waste [1012]. All these reasons explain why they are considered as the third generation of binders (after lime and OPC).

AAMs are produced from aluminosilicate(s) mixed with an alkaline solution [13]. AAMs can be divided into two main categories depending on the calcium $(\mathrm{Ca})$ content of the precursors [14], although other classifications are possible (Shi et al. [15] purposed five categories depending on the precursors used). Low Ca content AAMs are often called geopolymers. They are based on low Ca content precursors such as metakaolin (MK) or fly ash (FA) and the major reaction product is a N-A-S-H type gel $\left(\mathrm{Na}_{2} \mathrm{O}_{-} \mathrm{Al}_{2} \mathrm{O}_{3^{-}}\right.$ $\mathrm{SiO}_{2}-\mathrm{H}_{2} \mathrm{O}$ ) within a three dimensional network [16]. When the precursor employed has a high Ca content, the mechanisms of the activation and the reaction products are different and include a C-A-S-H type gel $\left(\mathrm{CaO}-\mathrm{Al}_{2} \mathrm{O}_{3}-\mathrm{SiO}_{2}-\mathrm{H}_{2} \mathrm{O}\right)$. GGBS is the most common precursor for high $\mathrm{Ca}$ AAMs. Several parameters influence AAM reactivity: mineral composition, morphology, and fineness. To achieve high performance, the precursor(s) must contain a sufficient amount of reactive glass, have a low water demand and be able to release aluminium easily [17]. Studies have been conducted on pure MK (paste [18-20], mortar [21] or concrete [22]). One of the main drawbacks of MK-geopolymer is a tendency to shrink and crack on drying [23,24]. Pure GGBS (paste [25], mortar [26,27]) have also been investigated. GGBS AAMs usually achieved good compressive strength [26,28], but these AAMs suffer from high shrinkage [29]. Melo Neto et al. [25] showed that pure GGBS AAMs show significantly higher shrinkage than OPC mortar. Moreover, these materials exhibit very short setting time [27]. 
Studies on pure FA AAMs (paste [30], mortar [31-33] or concrete [34]) indicated that FA geopolymer presents low reactivity compared with MK geopolymer and a thermal treatment is usually necessary to achieve reasonable properties (setting time and early age mechanical properties) [33]. Under ambient conditions, pure FA AAMs initial setting time is very long (more than $24 \mathrm{~h}$ ) because of the low reactivity of the FA but good mechanical properties can be achieved if the FA AAMs are thermally cured $[30,32,34]$. However, curing FA geopolymer at elevated temperature (usually between 40 and $90^{\circ} \mathrm{C}$ ) greatly increases the energy needed to produce the material [35].

Slightly fewer studies have concerned blended AAMs. Blended AAMs are defined as AAMs that contain at least two solid precursors. Properties of MK-FA AAMs mortar [36,37] were studied. Rajamma et al. [36] observed that adding MK to FA mortars increased the compressive strength. Logesh Kumar et al. [37] found different optimized MK/FA ratio depending on the liquid/solid ratio. GGBS-FA AAMs (paste [38-43], mortar [16,43,44] or concrete [45]) were also investigated. Kumar et al. [38] revealed that at $27^{\circ} \mathrm{C}$, the reaction of alkali-activated GGBS-FA blend paste is dominated by the GGBS activation (dissolution and precipitation of C-A-S-H) while at $60^{\circ} \mathrm{C}$ the reaction is due to combined interaction of FA and GGBS, which indicates that FA has lower reactivity than GGBS under ambient conditions. There is only small interaction of fly ash and GGBS probably due to different kinetics of dissolution process and distribution of species. Puligulla et al. [39] studied GGBS-FA blend pastes. They found that the calcium that dissolves from slag significantly influences both early and late age properties. The availability of free $\mathrm{Ca}$ ions seems to prolong FA dissolution and enhance geopolymer gel formation. It is proposed that the hardening process is initiated by the precipitation of $\mathrm{C}-\mathrm{A}-\mathrm{S}-\mathrm{H}$ and that rapid hardening continues due to accelerated geopolymerization. Liu et al. [40] achieved similar conclusions. Adding FA to GGBS decreases mechanical properties because FA used is less reactive than GGBS and has a low efficiency factor of 0.13. Yao et al. [41] studied the influence of FA addition in GGBS. As the previous quoted references, FA has a negative impact on compressive but it reduces shrinkage. MK-GGBS AAMs (paste [23,46-48], mortar [49]) have been investigated too. Bernal et al. [23] showed the beneficial effects of GGBS addition on MK AAMs compressive strength. In these systems, both type of reaction products C-A-S-H from GGBS and N-A-S-H from the metakaolin are able to coexist and have only small interactions [47]. Borges et al. [49] partly explained the compressive stress gain by a lower porosity. 
The studies mentioned above reveal that, under particular conditions, mixing two different precursors can give very interesting results. However, these studies have usually focused on the identification of a particular property under particular experimental conditions (curing, water/binder mass ratio, etc.). The aims of the present study were to measure and compare the performances of pure and blended AAMs. The blended AAMs were produced by associating two of the three most common solid precursors: MK, FA and GGBS in several proportions. As far as we know, there is no study combining these three aluminosilicate sources (in pairs) under exactly the same conditions (water/binder ratio, mixing procedure, curing, testing). Twenty-six mixes were made, associating two precursors with two activation rates (alkali-activation performed with sodium silicate solution). The mixtures were characterized in the fresh state (initial setting time) and the main properties useful for building applications (shrinkage, mass loss, compressive strength) were recorded and analysed. This experimental approach enabled precursor interactions to be analysed and interesting mix proportions to be identified. The significant differences observed with the addition of high Ca content GGBS were also analysed. All the samples were produced at ambient temperature. The fact that some AAMs need to be thermally treated to achieve a reasonable initial setting time, sufficient early strength or good mechanical properties is major problem. These thermally treated materials cannot be used on site such as concrete unless precast elements are routed. The alternative binders proposed here had to be produced under ambient conditions so as to be economically and environmentally competitive. 


\section{Materials}

\section{$2.1 \quad$ Binders}

Many materials can be alkali-activated. Most of them are produced from industrial by-products: FA, GGBS, rice husk ash, red mud, recycled glass [50], etc. This study focusses on the three main solid precursors: MK, FA and GGBS.

The MK used in this study is produced in the south of France (Argeco Developpement@) by flash calcination at around $700^{\circ} \mathrm{C}$. The kaolinite is transformed into MK by passing close to a flame for a few tenths of a second. This process is rapid and consumes less energy than classical MK production methods (such as a rotary oven [51]). XRD, ICP and Rietveld analysis performed by Pouhet [24] showed that this MK contained large amounts of impurities (quartz, anatase, mullite, kaolinite). The different compositions are presented in Table 1. The analyses of Pouhet [24] revealed that the amorphous phase contained $29 \%$ and $24 \%$ of $\mathrm{SiO}_{2}$ and $\mathrm{Al}_{2} \mathrm{O}_{3}$ respectively.

The FA used in this study came from France (Silicoline $\left.{ }^{\circledR}\right)$ and its chemical composition (in oxides) is detailed in Table 1. It was a coal power plant by-product certified to comply with the EN 450 standard. Its activity index at 28 days was between $75 \%$ and $83 \%$ (EN 196-1). XRD analysis showed that FA contained crystallized phases (quartz, mullite, hematite) and an amorphous phase. Rietveld analysis allowed us to quantify the crystallized phase contents and thus deduce the proportions of $\mathrm{SiO}_{2}$ and $\mathrm{Al}_{2} \mathrm{O}_{3}$ in the amorphous phase: 37.4 and $13.9 \%$, respectively (Table 1).

The GGBS used in this study was produced in France at Fos sur Mer (Ecocem®) and complied with standard EN 151-67-1. A diffusion hump seen on the XRD diagram confirmed that the GGBS was almost totally amorphous. It had a high specific surface (Blaine) of $4450 \mathrm{~cm}^{2} / \mathrm{g}$. The activity index at 28 days was $98 \%$ (EN 196-1).

Table 1. Raw material chemical composition.

\begin{tabular}{|c|c|c|c|c|c|c|c|c|c|c|c|c|c|c|c|c|}
\hline & & $\mathrm{SiO}_{2}$ & $\mathrm{Al}_{2} \mathrm{O}_{3}$ & $\mathrm{CaO}$ & $\mathrm{MgO}$ & $\mathrm{Fe}_{2} \mathrm{O}_{3}$ & $\mathrm{~K}_{2} \mathrm{O}$ & $\mathrm{Na}_{2} \mathrm{O}$ & $\mathrm{TiO}_{2}$ & $\mathrm{SO}_{3}$ & $\mathrm{H}_{2} \mathrm{O}$ & $\begin{array}{l}\text { Fire } \\
\text { loss }\end{array}$ & \multicolumn{4}{|c|}{ Amorphous phase } \\
\hline Metakaolin & $\%$ & 68.1 & 24.1 & 0.2 & 0.2 & 3.7 & 0.4 & 0.1 & 1.1 & 0.0 & - & 1.8 & 29.0 & 24.0 & 2.1 & 878.0 \\
\hline Fly ash & $\%$ & 49.7 & 26.3 & 1.7 & 1.6 & 6.0 & 4.2 & 0.6 & 0.8 & - & - & 2.5 & 37.4 & 13.9 & 4.5 & 85.4 \\
\hline Bétol 47T & $\%$ & 27.5 & - & - & - & - & - & 16.9 & - & - & 55.6 & - & - & - & - & 1.68 \\
\hline
\end{tabular}


The physical properties of the three precursors are summarized in Table 2. The densities of the three binders and GGBS and FA Blaine specific surface were provided by the producers. Due to its plate-like particle shape, MK Blaine specific surface cannot be measured. San Nicolas et al. [52] performed a BET analysis on the MK used in this study and found a high BET surface value $\left(14000 \mathrm{~cm}^{2} / \mathrm{g}\right)$. The particle size distributions were measured with a LASER granulometer, Cilas 1090 LD (Figure 1). Special precautions were taken during the post treatment of results. The optical refractive indices presented in Table 2 were used to calculate the particle size distributions with the Mie mathematical model as some errors can occur on the evolution of the fines (less than some microns) if the Fraunhofer approximation is used [53]. Figure 1 and Table 2 reveal that GGBS is much finer than MK and FA.

Table 2. Raw material physical characteristics, * = obtained with BET analysis [52].

\begin{tabular}{cccccccccc} 
& & \multicolumn{1}{c}{ Refractive index [54] } & \multicolumn{3}{c}{ Particle size distribution } \\
\cline { 2 - 10 } & Density & $\begin{array}{c}\text { Blaine specific } \\
\text { surface }\end{array}$ & Real part & $\begin{array}{c}\text { Imaginary } \\
\text { part }\end{array}$ & $\mathrm{d}_{10}$ & $\mathrm{~d}_{50}$ & $\mathrm{~d}_{90}$ & $\mathrm{~d}_{\text {moy }}$ \\
\cline { 2 - 10 } & $\mathrm{kg} / \mathrm{m}^{3}$ & $\mathrm{~cm}^{2} / \mathrm{g}$ & & & $\mu \mathrm{m}$ & $\mu \mathrm{m}$ & $\mu \mathrm{m}$ & $\mu \mathrm{m}$ \\
\hline $\begin{array}{c}\text { Measurement } \\
\text { precision }\end{array}$ & 100 & 200 & - & - & 0.2 & 0.2 & 0.2 & 0.2 \\
\hline $\begin{array}{c}\text { Metakaolin } \\
\text { GGBS }\end{array}$ & 2500 & $14000^{*}$ & 1.65 & 0.1 & 5.1 & 28.0 & 81.9 & 36.8 \\
Fly ash & 2900 & 4450 & 1.65 & 0.1 & 2.5 & 12.5 & 33.1 & 15.0 \\
& 2200 & 2730 & 1.73 & 0.1 & 6.7 & 37.7 & 97.0 & 37.7
\end{tabular}

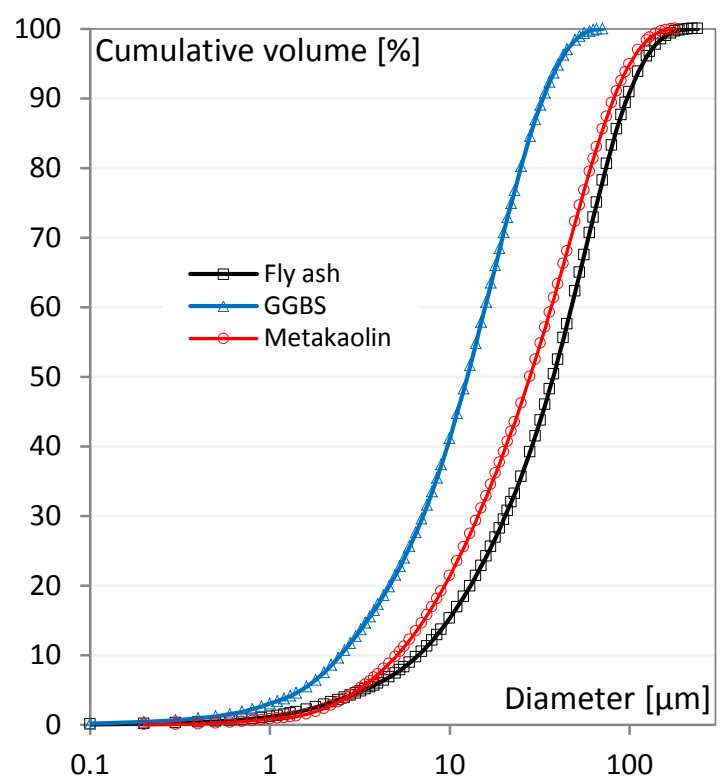

Figure 1. Raw material particle size distributions. 


\subsection{Activator}

The alkali activation was performed with a commercial sodium silicate solution (Bétol 47T - Woellner®), the composition of which is given in Table 1. The $\mathrm{SiO}_{2} / \mathrm{Na}_{2} \mathrm{O}$ molar ratio was 1.68. Caustic soda was added to improve the activation (3.2\% of the mass of the commercial alkaline solution). The term "activator" is used to defined the solid remaining material obtained if all the water was evaporated (the solid part) from the alkaline solution (commercial alkaline solution $+\mathrm{NaOH}$ ). Activator content of the alkaline solution is $44.4 \%$.

\section{Methods}

\subsection{Mix-design}

All the mixes made in this study are presented in ternary diagrams (Figure 2). The design of experiments was built by changing the proportion of three raw materials: the activator (the dry extract of the alkaline solution) and the two precursors (chosen from MK, FA and GGBS). The literature shows that single precursor AAMs can suffer from different problems. The aim is to find an appropriate formulation to produce AAMs with better properties. Moreover, different raw material consumes different quantity of alkaline solution which has a great influence on the final price of product. Reducing its content is necessary to reduce AAMs cost. The 26 mixes were made with the same water to binder mass ratio, W/B $=0.36$. The binder comprised the two powders (MK, FA, GGBS) and the activator. The water came from the alkaline solution and enough water was added to obtain the constant W/B ratio for each mix. Hereafter, the samples will be designated as: $A_{i} B_{j} C_{k}$ where $A$ is the activator and $i$ the associated percentage; $\mathrm{B}$ is the first solid precursor and $\mathrm{j}$ its percentage; $\mathrm{C}$ is the second solid precursor and $\mathrm{k}$ its percentage. Each sample verified $\mathrm{i}+\mathrm{j}+\mathrm{k}=100$. An example of ternary reading is presented on Figure 3. The minimum value of the W/B ratio was evaluated with preliminary tests on samples that contained only MK $\left(\mathrm{A}_{25} \mathrm{MK}_{75}\right.$ and $\mathrm{A}_{15} \mathrm{MK}_{85}$ - Figure 2). MK led to higher water demand than GGBS and FA [55] because of the plate-like morphology of MK particles. The minimum W/B was defined from the minimum fluidity required to fill all the moulds (Table 3) without vibration for the pure MK AAMs. With lower W/B, it became very difficult to fill all the moulds without vibration for the pure MK pastes. 

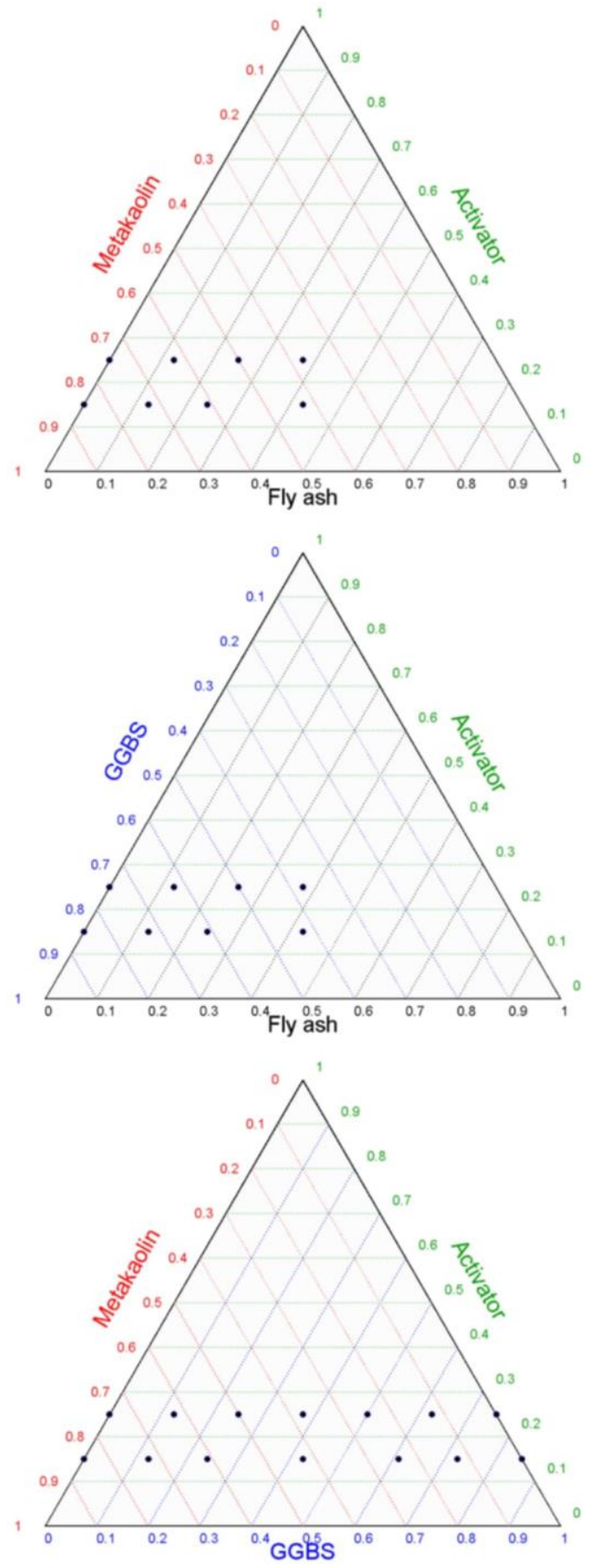

Figure 2. Mix design: Ternary diagrams.

Each ternary mixture was made with two activator percentages, $15 \%$ and $25 \%$, to observe the influence of the quantity of alkaline activator on the AAM properties. These percentages will be referred to as low (15\%) and high activation rates (25\%) hereafter. The first two ternary mixtures had limited FA content because of the low reactivity of FA at ambient temperature (Figure 2). As the samples were unmoulded after $24 \mathrm{~h}$, higher FA content samples were impossible to unmould for MK-FA mixtures without breaking them. Preliminary tests on GGBS-FA mixtures revealed that it was possible to increase FA content but very low mechanical performances were achieved and explained why FA contents studied of GGBS-FA 
blends were voluntarily maintained as low as for MK-FA blends. The last ternary mixture (MK-GGBS) was made in 14 different mix proportions. MK and GGBS could be associated in any proportion without causing unmoulding problems after 24. All the compositions and associated results are summarized in Table 4.

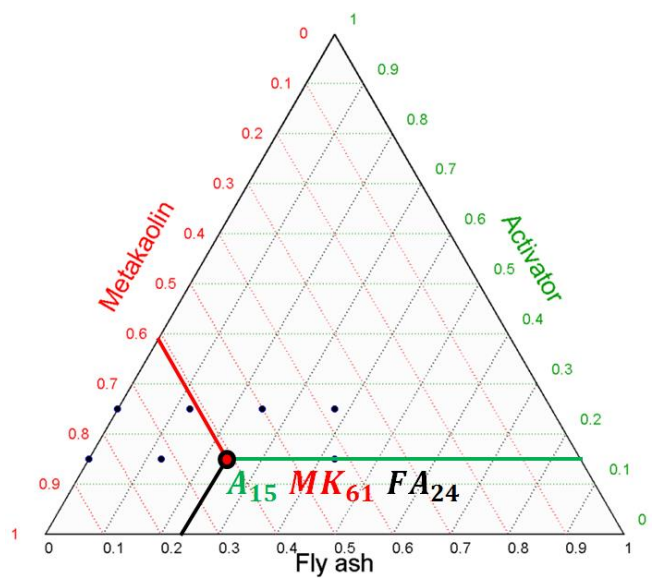

Figure 3. Ternary reading: an example.

\subsection{Sample production and characterization}

To produce the different samples (Table 3) of the three ternary mixes, the dry powders were first mixed to obtain a homogeneous powder. The soda was diluted in the additional water and this solution was mixed with the alkaline solution. The resulting liquid was added to the powder (the moment of this addition defined the initial time, $\mathrm{t}=0$ ) and mixed for 1 minute at low speed then 2 minutes at high speed using an ordinary mixer (Automix 65 - Controls ${ }^{\circledR}$ ). The paste was then cast in the different moulds (Table 3). To prevent water evaporation, the moulds were covered with plastic sheets. They were then placed in a room at $20^{\circ} \mathrm{C}$ for $24 \mathrm{~h}$.

Table 3. Sample characterization.

\begin{tabular}{llll} 
Test & Quantity measured & Mould & $\begin{array}{l}\text { Time } \\
\text { [days] }\end{array}$ \\
\hline Initial setting time & mins & Truncated conical moulds - height $40 \mathrm{~mm}$ - diameter $80 \mathrm{~mm}$ & 0 \\
Compressive strength & $\mathrm{MPa}$ & Cubic (x 8) - height $20 \mathrm{~mm}$ & $1,7,28$ \\
Mass loss & $\%$ & Prismatic (x 3) - 20 x 20 x $160 \mathrm{~mm}$ & $1,2,7,14$, \\
Shrinkage & $\%$ & & 21,28
\end{tabular}

The paste setting time was characterized in the fresh state using an automatic Vicat device (Vicatronic $®)$. The Vicat initial setting time was calculated as the time that elapsed between the initial contact $(\mathrm{t}=0)$ of dry powder and alkaline solution and the time when the probe penetrated to $25 \mathrm{~mm}$ from the bottom of 
the mould (ASTM C191- 01 standard [56]). Cubic and prismatic samples were unmoulded after $24 \mathrm{~h}$. Cubic samples were stored in plastic bags to limit water loss for strength measurements. Compressive strength was measured after 1, 7 and 28 days on cubic samples. Eight samples were tested at each term (100 kN IGM® press, loading speed $0.5 \mathrm{kN} / \mathrm{s})$ to obtain a representative average of the compressive strength. Prismatic samples were placed at $20^{\circ} \mathrm{C}$ and $50 \% \mathrm{HR}$ without any protection for shrinkage measurements. The shrinkage tests were based on an adaptation of the ASTM C 596 - 01 standard [57]. Prismatic samples (3 per composition) were weighed and measured at 1, 2, 7, 14, 21 and 28 days. Samples were measured using a length comparator with a precision of $\pm 0.01 \mathrm{~mm}$. The shrinkage was calculated as $\left(1-1_{0}\right) / l_{0}$, where 1 is the measured dimension of the sample and $1_{0}$ is the sample dimension immediately after unmoulding. The mass loss was calculated as $\left(\mathrm{m}-\mathrm{m}_{0}\right) / \mathrm{m}_{0}$, where $\mathrm{m}$ is the weight of the sample and $\mathrm{m}_{0}$ is the sample weight immediately after unmoulding. Thus, the first mass loss and shrinkage results are obtained after 2 days which corresponds to one day after unmoulding (under shrinkage conditions). 


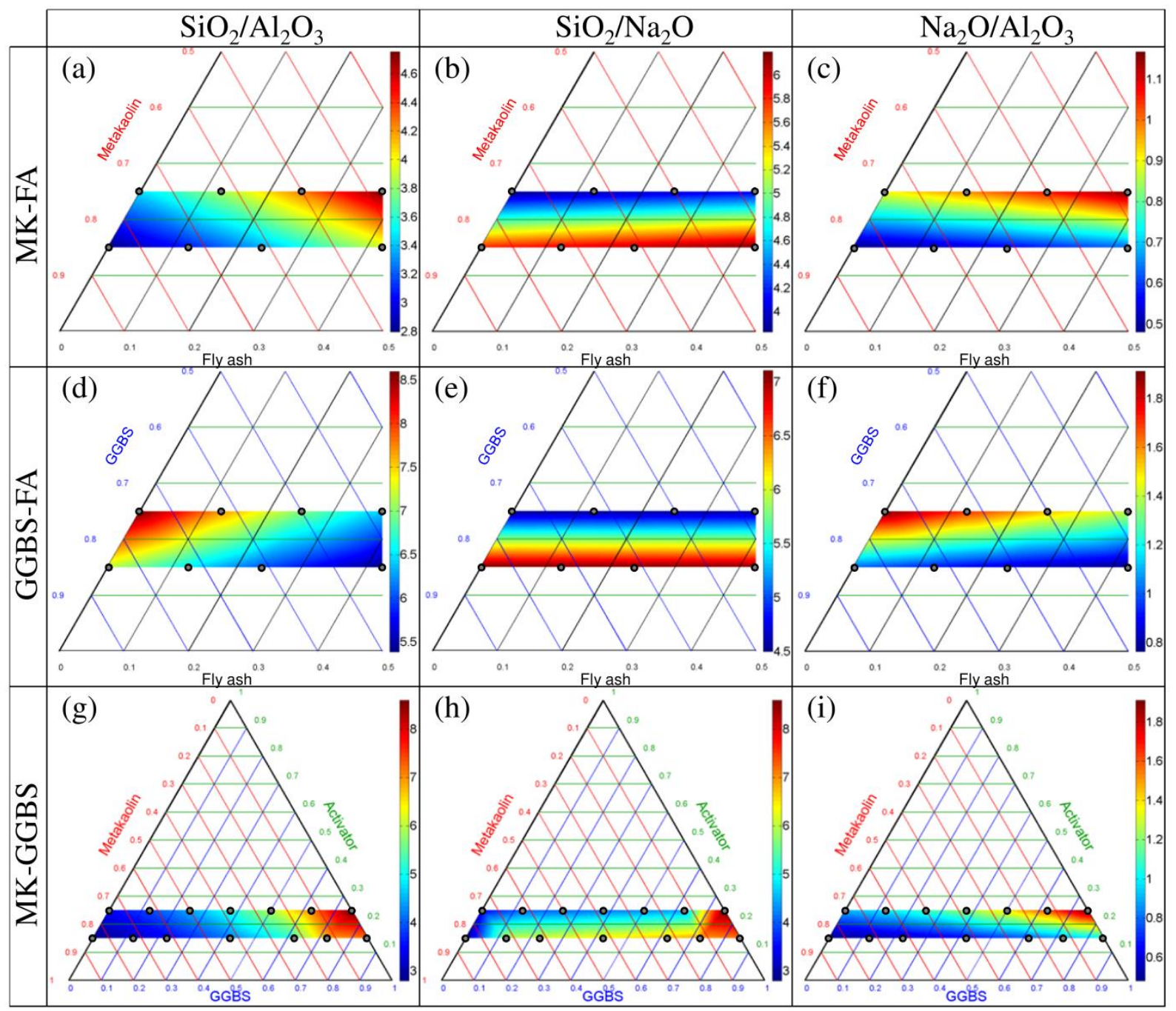

Figure 4. Molar ratios $\left(\mathrm{SiO}_{2} / \mathrm{Al}_{2} \mathrm{O}_{3}, \mathrm{SiO}_{2} / \mathrm{Na}_{2} \mathrm{O}\right.$ and $\left.\mathrm{Na}_{2} \mathrm{O} / \mathrm{Al}_{2} \mathrm{O}_{3}\right)$.

Figure 4 presents three overall molar ratios (dry powder + alkaline solution) introduced for geopolymers $\left(\mathrm{SiO}_{2} / \mathrm{Al}_{2} \mathrm{O}_{3}, \mathrm{SiO}_{2} / \mathrm{Na}_{2} \mathrm{O}\right.$ and $\left.\mathrm{Na}_{2} \mathrm{O} / \mathrm{Al}_{2} \mathrm{O}_{3}\right)$. These ratios were calculated considering the amorphous quantity (Table 1) of each oxide because the crystallized part did not react. Geopolymer properties are highly dependent on these molar ratios [20,22]. MK-FA AAMs presented $\mathrm{SiO}_{2} / \mathrm{Al}_{2} \mathrm{O}_{3}$ ratios ranging from 2.80 to 4.75 (Figure 4 - (a)). The highest value (in red on Figure 4) was obtained for the samples that simultaneously contained the highest proportions of FA and activator $\left(\mathrm{A}_{25} \mathrm{MK}_{37.5} \mathrm{FA}_{37.5}\right)$ because $\mathrm{MK}$ contains less amorphous $\mathrm{SiO}_{2}$ than either FA or activator (Table 1). The $\mathrm{SiO}_{2} / \mathrm{Na}_{2} \mathrm{O}$ ratio of $\mathrm{MK}-\mathrm{FA}$ AAMs mostly depended on the activator content as it provided nearly all the sodium oxide $\mathrm{Na}_{2} \mathrm{O}$, and the amorphous $\mathrm{SiO}_{2}$ contents of MK and FA were quite similar (Table 1). For low activation (activator $=$ $15 \%)$, the $\mathrm{SiO}_{2} / \mathrm{Na}_{2} \mathrm{O}$ ratios were maximums $\left(\mathrm{SiO}_{2} / \mathrm{Na}_{2} \mathrm{O} \geq 5.81\right)$. The same logic explains why $\mathrm{Na}_{2} \mathrm{O} / \mathrm{Al}_{2} \mathrm{O}_{3}$ were maximum for high activation (Figure 4 (c)). 
The $\mathrm{SiO}_{2} / \mathrm{Al}_{2} \mathrm{O}_{3}$ ratio evolution was different with GGBS-FA because GGBS was nearly $100 \%$ amorphous and thus had a high $\mathrm{SiO}_{2} / \mathrm{Al}_{2} \mathrm{O}_{3}$ ratio. The highest $\mathrm{SiO}_{2} / \mathrm{Al}_{2} \mathrm{O}_{3}$ value (Figure 4 (d)) was obtained by the sample that simultaneously contained the highest proportions of GGBS and activator $\left(\mathrm{A}_{25} \mathrm{GGBS}_{85}\right)$. As for MK-FA AAMs, the $\mathrm{SiO}_{2} / \mathrm{Na}_{2} \mathrm{O}$ and $\mathrm{Na}_{2} \mathrm{O} / \mathrm{Al}_{2} \mathrm{O}_{3}$ ratios of GGBS-FA mostly depended on activator content (Figure 4 (e) and (f)).

For MK-GGBS, the $\mathrm{SiO}_{2} / \mathrm{Al}_{2} \mathrm{O}_{3}$ ratio evolved significantly. It was 3.46 and 2.80 for $\mathrm{A}_{25} \mathrm{MK}_{75}$ and $\mathrm{A}_{15} \mathrm{MK}_{85}$ respectively (Figure $4(\mathrm{~g})$ ). Much higher values were observed for pure GGBS AAMs (8.60 for $\mathrm{A}_{25} \mathrm{MK}_{75}$ and 7.19 for $\mathrm{A}_{15} \mathrm{MK}_{85}$ ). As seen above, the $\mathrm{SiO}_{2} / \mathrm{Na}_{2} \mathrm{O}$ ratio of MK-GGBS AAMs depended on the activation rate but, as there was also a significant difference in $\mathrm{SiO}_{2}$ content between $\mathrm{MK}$ and GGBS, significant $\mathrm{SiO}_{2} / \mathrm{Na}_{2} \mathrm{O}$ variations were observed when changing the MK/GGBS proportion.

For high $\mathrm{Ca}$ content AAMs, the presence of $\mathrm{Ca}$ significantly changed the chemical reaction and the species produced [14]. For this reason, the properties of high Ca content AAMs might also depend on $\mathrm{CaO} / \mathrm{Al}_{2} \mathrm{O}_{3}$ and $\mathrm{CaO} / \mathrm{SiO}_{2}$ ratios. These ratios are presented in Figure 5:

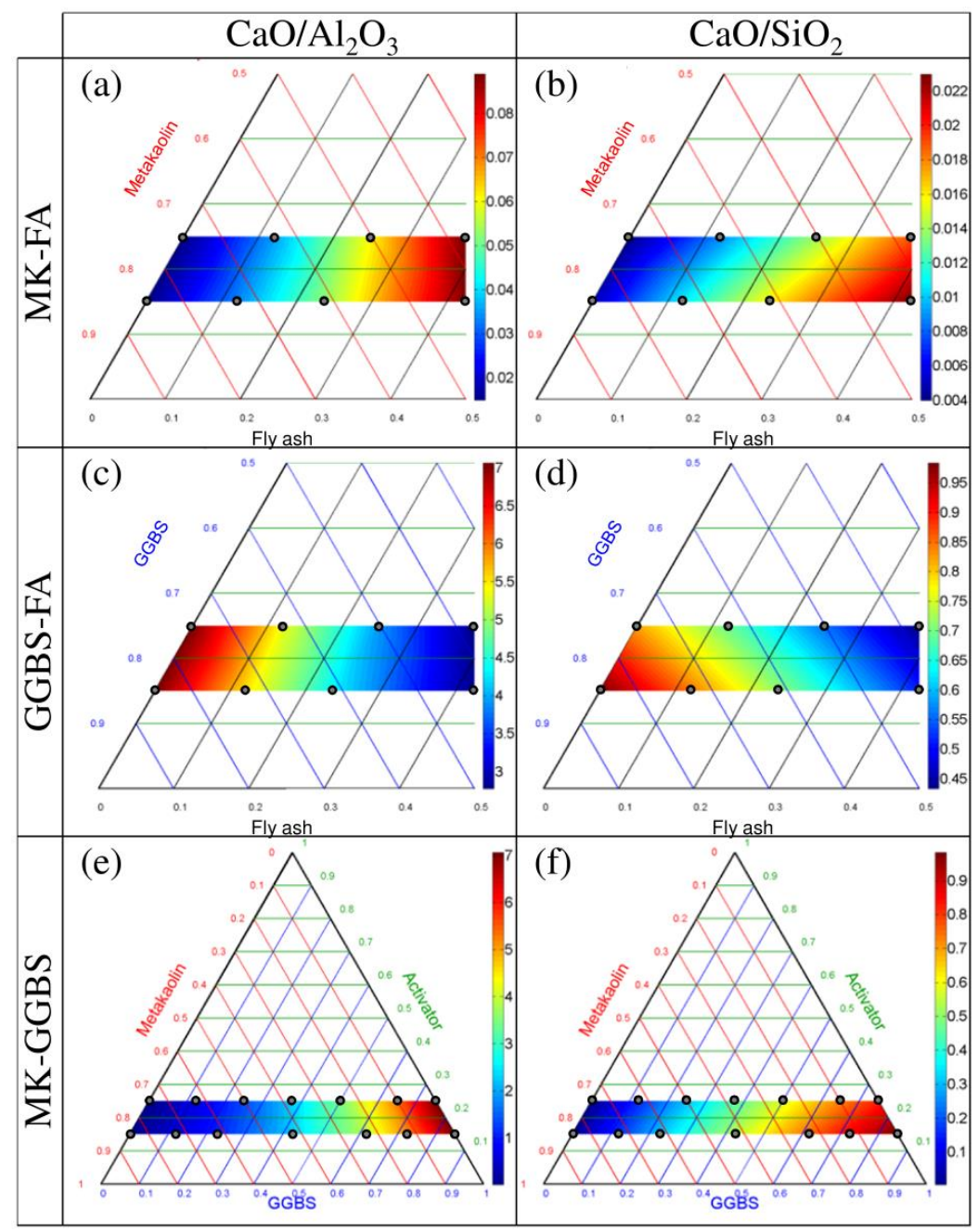

Figure 5. Molar ratios $\left(\mathrm{CaO} / \mathrm{Al}_{2} \mathrm{O}_{3}\right.$ and $\left.\mathrm{CaO} / \mathrm{SiO}_{2}\right)$. 
FA contained a small amount of $\mathrm{Ca}$ (Table 1), explaining why the $\mathrm{CaO} / \mathrm{Al}_{2} \mathrm{O}_{3}$ and $\mathrm{CaO} / \mathrm{SiO}_{2}$ ratios of MK-FA AAMs increased a little with FA content (Figure 5 (a) and (b)). However, the ratios remained small $\left(\mathrm{CaO} / \mathrm{Al}_{2} \mathrm{O}_{3} \leq 0.18\right.$ and $\left.\mathrm{CaO} / \mathrm{SiO}_{2} \leq 0.05\right)$ and were maximum for the two MK-FA samples with the highest FA content, $\mathrm{A}_{25} \mathrm{MK}_{37.5} \mathrm{FA}_{37.5}$ and $\mathrm{A}_{15} \mathrm{MK}_{42.5} \mathrm{FA}_{42.5}$.

These two ratios increased considerably for both GGBS-FA and MK-GGBS samples due to the high Ca content of GGBS. The $\mathrm{CaO} / \mathrm{Al}_{2} \mathrm{O}_{3}$ ratio was greater than 7 for pure GGBS samples (Figure 5 (c) and (e)). The $\mathrm{CaO} / \mathrm{SiO}_{2}$ ratios also increased with GGBS content, to reach values near 1 (Figure 5 (d) and (f)). Increasing the $\mathrm{Ca}$ content would lead to a different chemical process and different chemical products from those obtained with low Ca AAMs [58].

\section{$4 \quad$ Results}

\subsection{Initial setting time}

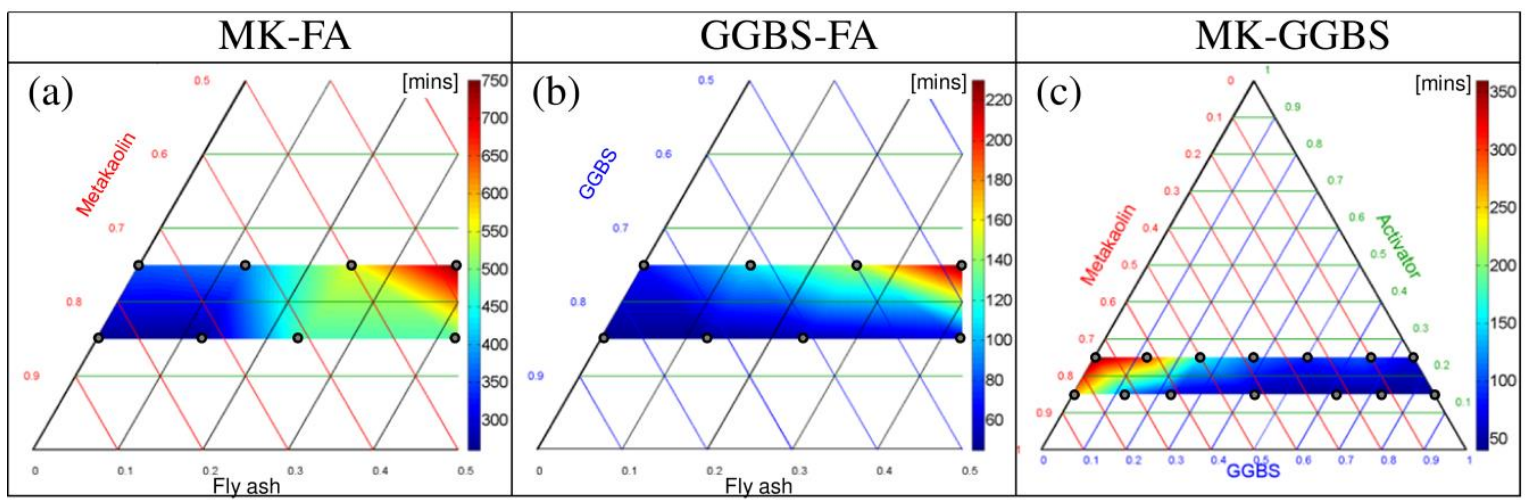

Figure 6. Initial setting time.

The initial setting time results are presented in Figure 6. Pure MK initial setting times (Figure 6 (a)) were 360 and 265 minutes for $\mathrm{A}_{25} \mathrm{MK}_{75}\left(\mathrm{SiO}_{2} / \mathrm{Al}_{2} \mathrm{O}_{3}=3.46\right)$ and $\mathrm{A}_{15} \mathrm{MK}_{85}\left(\mathrm{SiO}_{2} / \mathrm{Al}_{2} \mathrm{O}_{3}=2.80\right)$. As stated in the literature [59], for pure $\mathrm{MK}$, the initial setting time was shorter for lower $\mathrm{SiO}_{2} / \mathrm{Al}_{2} \mathrm{O}_{3}$ ratios. Adding FA increased this ratio and, above all, FA showed extremely low reactivity under ambient conditions. These two reasons explained why the initial setting time increased with FA addition, reaching 750 minutes for $\mathrm{A}_{25} \mathrm{MK}_{37.5} \mathrm{FA}_{37.5}\left(\mathrm{SiO}_{2} / \mathrm{Al}_{2} \mathrm{O}_{3}=4.75\right)$. It should not be forgotten that the higher water demand of MK could lead to a decrease in workability in the mixtures with high MK contents. Thus it could have a slight effect on the initial setting time of the mixtures.

For GGBS-FA samples, the highest $\mathrm{SiO}_{2} / \mathrm{Al}_{2} \mathrm{O}_{3}$ ratio $\left(\mathrm{A}_{25} \mathrm{GGBS}_{37.5} \mathrm{FA}_{37.5}\right)$ was also associated with the longest initial setting time (Figure 6 (b) - 230 minutes) but the shortest initial setting time was due to the 
high Ca content of GGBS. Ca significantly decreased the initial setting time compared to those of MKFA blends. In GGBS AAMs, both C-A-S-H and aluminosilicate phases (N-A-S-H) observed on geopolymer AAMs are present [60]. The hydration products of alkali-activated GGBS are controlled by the composition of the GGBS, the type of activator and the $\mathrm{pH}$ environment. The $\mathrm{pH}$ is controlled either by the activator quantity or the GGBS content (GGBS is basic). The main hydration product is C-A-S-H whatever the activator employed [14]. However AFm, hydrotalcite $\left(\mathrm{Mg}_{6} \mathrm{Al}_{2} \mathrm{CO}_{3}(\mathrm{OH})_{16} \cdot 4 \mathrm{H}_{2} \mathrm{O}\right)$ and calcite can also be found if the GGBS is activated with $\mathrm{NaOH}$ [61]. The hardening process is initiated by the fast precipitation of C-A-S-H gels. The lowest initial setting times were obtained for the pure GGBS, which corresponded to the highest Ca content (Figure 5 (c) and (d)). This is in agreement with the findings of Kumar et al. [38] and Gao et al. [16]. Ca is easily converted into $\mathrm{Ca}^{2+}$ ions, which quickly associate with the silicates coming from the alkaline solution to produce C-A-S-H. A gradient of $\mathrm{Ca}^{2+}$ concentration appears between the solution and the GGBS particles, promoting the dissolution of Ca into the solution. According to Puligilla and Mondal [39], GGBS also enhances long-term polymerization because the medium is more basic. The fast initial setting observed for pure GGBS AAMs can also be explained by the fineness of the GGBS (Figure 1). Adding FA, which has a very low reactivity at ambient conditions, significantly delayed the initial setting time (Figure 6 (b)) and explains why higher FA content was not considered. Kumar et al. [38] show that the setting time of GGBS-FA paste can be significantly reduced by curing the sample at $60^{\circ} \mathrm{C}$. However, this is associated with higher energy consumption and was thus banned from this study. The compatibility of the two cementitious gels (C-A-S-H and N-A-S-H) has important implications for AAMs with high Ca content, in which both products might be expected. Under high $\mathrm{pH}$ conditions $(\mathrm{pH}>12)$, the presence of $\mathrm{Ca}$ degrades $\mathrm{N}-\mathrm{A}-\mathrm{S}-\mathrm{H}$ and promotes $\mathrm{C}-\mathrm{A}-\mathrm{S}-\mathrm{H}$ formation. Replacing a large proportion of low Ca content aluminosilicate precursors by GGBS would lead to a high $\mathrm{pH}$ medium. If the $\mathrm{pH}$ is low enough $(<12), \mathrm{N}-\mathrm{A}-\mathrm{S}-\mathrm{H}$ persists [62].

For MK-GGBS AAMs, the highest Ca content (Figure 5 (e) and (f)) was also associated with the lowest initial setting time (Figure 6 (c) - 70 and 45 minutes for $\mathrm{A}_{25} \mathrm{GGBS}_{75}$ and $\mathrm{A}_{15} \mathrm{GGBS}_{85}$, respectively) for the same reasons as for GGBS-FA AAMs.

Very fast initial setting time (less than one hour) can cause placing problems on a construction site. The proportions of raw materials (ternary - Figure 2) must be adapted according to the initial setting time requirements. Thus, varying the proportions of the precursors should allow us to manage the setting time. 


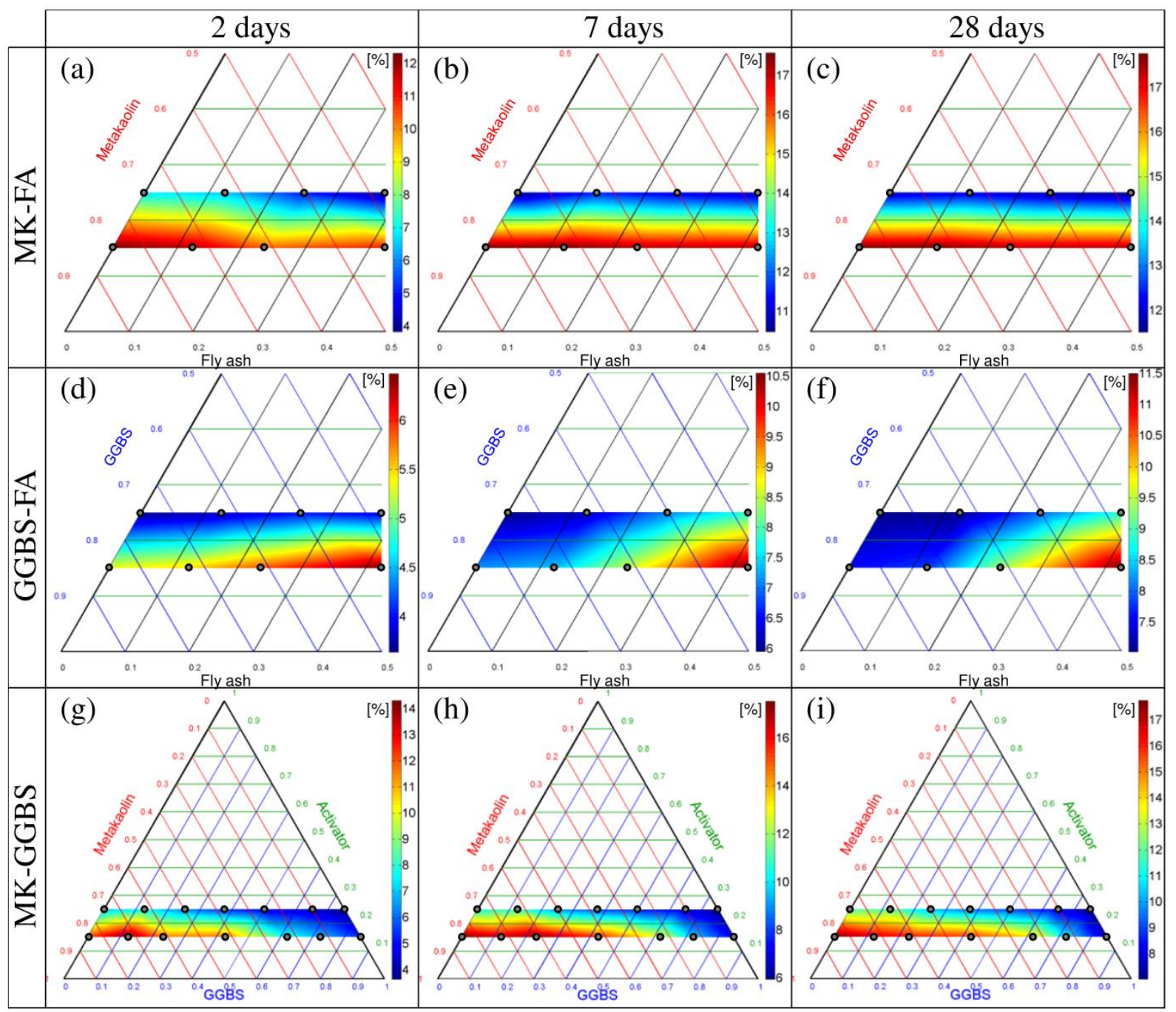

Figure 7. Mass loss.

The mass loss results are presented in Figure 7. This phenomenon has not been widely studied in the literature for blended AAMs. As a reminder, after only $24 \mathrm{~h}$, our samples were unmoulded and placed directly in unrestrained shrinkage conditions $\left(20^{\circ} \mathrm{C}-50 \% \mathrm{HR}\right)$. These conditions are harsh for early age samples (even more so because there is no aggregate to restrain the shrinkage). Originally, all the samples contained exactly the same amount of water (coming from the alkaline solution and a water addition to reach the desired fixed W/B ratio of 0.36 ). Three types of water were considered: chemically bound, physically absorbed and free. The chemically bound water was not evaporable at ambient temperature. However, major differences appeared at 28 days: the maximum mass loss was $17.8 \%\left(\mathrm{~A}_{15} \mathrm{MK}_{72.5} \mathrm{FA}_{12.5}\right)$ and the minimum was $7.0 \%\left(\mathrm{~A}_{25} \mathrm{GGBS}_{75}\right)$. 
For MK-FA, mass loss mostly depended on activator content (Figure 7 (a), (b) and (c)) and was maximum with low activation rate (high $\mathrm{SiO}_{2} / \mathrm{NA}_{2} \mathrm{O}$ ratio). Mass loss was a very fast phenomenon. After 2 days ( 1 day under unrestrained shrinkage conditions), mass loss had reach high values, from $4 \%$ to $12 \%$ (Figure 7). Furthermore, as the FA contained a small amount of $\mathrm{Ca}$, a higher activation could have created more C-A-S-H and more chemically bound water.

Replacing MK by GGBS led to lower mass loss values. This is in agreement with the formation of C-A$\mathrm{S}-\mathrm{H}$ structures. GGBS contributed a significant amount of $\mathrm{Ca}$ that quickly reacted with water which explained the short initial setting time observed in Figure 6 (b). In contrast to the geopolymerization process observed for low $\mathrm{Ca}$ content, in which the water was finally released, some water was incorporated in the C-A-S-H structure and chemically bound. This explains why mass loss was lower for GGBS-FA than MK-FA AAMs. The maximum mass loss was observed for higher FA content and lower activator content $\left(11.5 \%-\mathrm{A}_{15} \mathrm{GGBS}_{42.5} \mathrm{FA}_{42.5}\right)$. For this sample, the $\mathrm{pH}$ might have been lower because the activation rate was low and GGBS content was minimum. Thus, C-A-S-H gel formation (and chemical binding of water) may have been limited and could explain the large mass loss observed. Adding GGBS may increase the $\mathrm{pH}$ and lead to higher C-A-S-H formation [62] which would explain the lower mass loss values obtained for the higher GGBS content at 28 days (Figure 7 (f)).

The influence of Ca content on mass loss is also observable on MK-GGBS AAMs in Figure 7 (g), (h) and (i). For higher GGBS content, the mass loss was also reduced because of massive C-A-S-H formation (only $7.0 \%$ and $7.6 \%$ mass loss for $\mathrm{A}_{25} \mathrm{GGBS}_{75}$ and $\mathrm{A}_{15} \mathrm{GGBS}_{85}$ after 28 days, respectively). Increasing the MK content simultaneously reduced the $\mathrm{CaO} / \mathrm{Al}_{2} \mathrm{O}_{3}$ and $\mathrm{CaO} / \mathrm{SiO}_{2}$ ratios (Figure 5 (e) and (f)) and may have reduced the $\mathrm{pH}$. It could enhance N-A-S-H formation and lead to higher water loss because $\mathrm{N}$ A-S-H gel releases water after geopolymerization. Water plays the role of a reaction medium, but resides within pores in the gel [4]. Significant difference was also observed between the pure MKs although they did not contain $\mathrm{Ca}$. Lower activation led to higher mass loss $\left(17.8 \%\right.$ and $11.9 \%$ for $\mathrm{A}_{15} \mathrm{MK}_{85}$ and $\mathrm{A}_{25} \mathrm{MK}_{75}$, respectively). Because the geopolymer matrix was poorly formed, a relatively large amount of water was free and could evaporate easily. The microstructure was weak and little water was chemically bound, so water loss became impossible to prevent after only $24 \mathrm{~h}$. This water release was detrimental to the AAMs' properties (compressive strength, shrinkage, etc.) because the geopolymerization process occurred in an aqueous medium. The presence of water is indispensable for good geopolymerization. We think that the relationship between Ca content and mass loss could only be made in the same category of 
$\mathrm{AAM}$, as the products of reaction are completely different depending on the presence of $\mathrm{Ca}$ (for instance AAM containing GGBS produced some C-A-S-H, while MK-FA mixtures produced only aluminosilicates). The average of the mass loss relative standard deviation obtained for the 26 mixes is presented in Table 4 (last line). The highest mass loss relative standard deviation was observed at 2 days while the mass loss rate was fast. However, the value was quite small (3.8\%), which indicates good repeatability of the measurements.

\subsection{Shrinkage}

Most studies on AAMs have focused on mechanical and microstructural properties. However, shrinkage problems cannot be ignored [27,43,44]. Estimating and limiting this volume change is extremely important if the use of AAMs is to spread in civil engineering applications. In this part the total shrinkage was measured. The total shrinkage of AAMs is caused by several concurrent phenomena, chemical shrinkage, self-desiccation shrinkage and drying shrinkage. The sum of chemical and self-desiccation shrinkages is called autogenous shrinkage. 


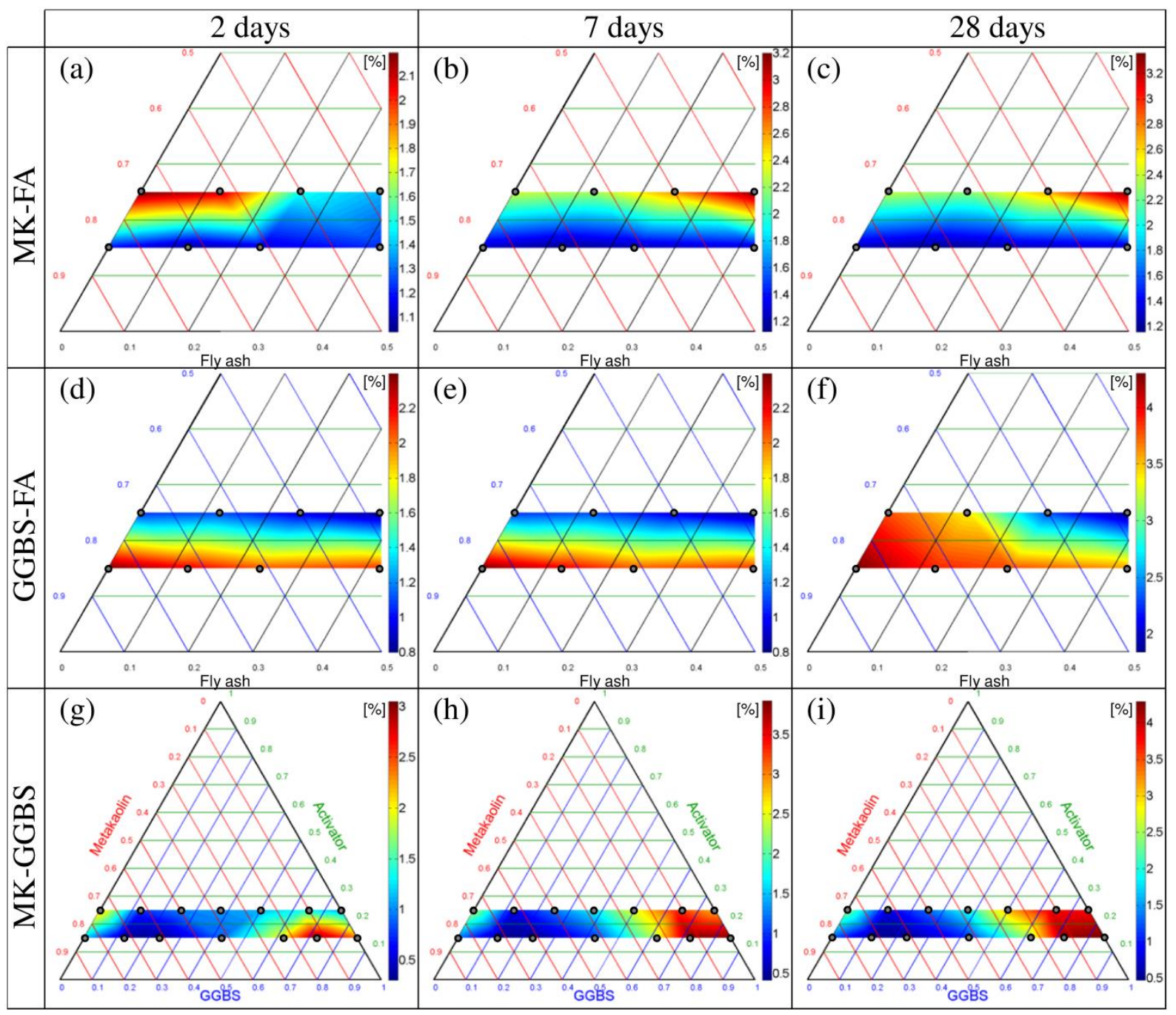

Figure 8. Shrinkage.

The shrinkage results are presented in Figure 7 . Under the severe shrinkage conditions employed $\left(20^{\circ} \mathrm{C}\right.$ -

$50 \% \mathrm{HR}-24 \mathrm{~h}$ after sample preparation), some samples reached huge shrinkage values. The greatest shrinkage, at 28 days, was $4.3 \%\left(\mathrm{~A}_{15} \mathrm{GGBS}_{85}\right)$. For the three ternary compositions, it should be noted that, after 2 days ( 1 day under shrinkage test), the shrinkage values were already significant, in agreement with $[25,27]$.

At 2 days, for geopolymers, higher shrinkage values are obtained for AAMs made with pure MK or MKFA having a high $\mathrm{MK}$ content and for high activation rates $\left(2.2 \%\right.$ and $2.1 \%$ for $\mathrm{A}_{25} \mathrm{MK}_{75}$ and $\mathrm{A}_{25} \mathrm{MK}_{62.5} \mathrm{FA}_{12.5}$ respectively). For geopolymer, only a small percentage of the mixing water remains as pore water in the geopolymer gel. There is a large excess of unbound or free water, which can evaporate from the hardened state at low relative humidity at ambient temperature [18]. These high total shrinkage values can be partially explained by the significant mass loss observed after only 2 days (Figure 7 (a)). However, the maximum mass loss values (Figure 7 (a)) do not correspond to the maximum shrinkage 
values (Figure 7 (a)), which means that self-desiccation shrinkage plays an important role when the activation rate and MK content are high, at 2 days. At 28 days, the highest shrinkage values are obtained for the highest amount of $\mathrm{FA}$ and high alkali activation (3.4\% for $\mathrm{A}_{25} \mathrm{MK}_{37.5} \mathrm{FA}_{37.5}$, at 28 days) which corresponds to the highest $\mathrm{Na}_{2} \mathrm{O} / \mathrm{Al}_{2} \mathrm{O}_{3}$ ratio. At low temperature $\left(20^{\circ} \mathrm{C}\right)$, the $\mathrm{FA}$ are not well activated and do not participate completely in the strength gain of these samples. After 24 h, only MK had partially reacted and these two samples would have very low mechanical properties (see Figure 9 (a) $-R_{c}=$ 3.7 $\mathrm{MPa}$ for $\mathrm{A}_{25} \mathrm{MK}_{37.5} \mathrm{FA}_{37.5}$ ). It is reasonable to say that, at 28 days, the contribution of $\mathrm{FA}$ to the stress gain is very small. The high shrinkage values can be explained by the inability of the weak microstructure to prevent volume change caused by drying and autogenous shrinkage. For pure MK, shrinkage remains high (2.4 and $1.3 \%$ for $\mathrm{A}_{25} \mathrm{MK}_{75}$ and $\mathrm{A}_{15} \mathrm{MK}_{85}$ at 28 days).

The shrinkage of pure GGBS AAMs is presented in Figure 7 ((d), (e) and (f)). At 2 days, a significant difference is seen between high and low activation rates. The shrinkage values are $1.1 \%$ and $2.4 \%$ for $\mathrm{A}_{25} \mathrm{GGBS}_{75}$ and $\mathrm{A}_{15} \mathrm{GGBS}_{85}$ respectively. For $\mathrm{A}_{25} \mathrm{GGBS}_{75}$, the activation is fast and a larger quantity of GGBS is converted into C-A-S-H when the samples are unmoulded. The degree of hydration is higher, which would results in an increase in C-A-S-H volume and a decrease in porosity. $\mathrm{A}_{25} \mathrm{GGBS}_{75}$ trapped more water than $\mathrm{A}_{15} \mathrm{GGBS}_{85}$ (Figure 7 (d)). The mass losses were $3.6 \%$ and $5.3 \%$ for $\mathrm{A}_{25} \mathrm{GGBS}_{75}$ and $\mathrm{A}_{15} \mathrm{GGBS}_{85}$, respectively, at 2 days. Thus, the significant shrinkage differences may be explained by a better ability of $\mathrm{A}_{25} \mathrm{GGBS}_{75}$ to convert free water into chemically bound water, thus preventing fast drying shrinkage. At 28 days, the highest shrinkage value was obtained by $\mathrm{A}_{15} \mathrm{GGBS}_{85}(4.3 \%)$ and correspond to the highest $\mathrm{CaO} / \mathrm{SiO}_{2}$ ratio. $\mathrm{A}_{25} \mathrm{GGBS}_{75}$ shrinkage was 3.6\%. Under these conditions, mass losses were relatively low and similar (7.0 and 7.6\% for $\mathrm{A}_{25} \mathrm{GGBS}_{75}$ and $\mathrm{A}_{15} \mathrm{GGBS}_{85}$ - Figure 7 (f)) compared to the other MK-FA AAMs. Actually, compared to $\mathrm{A}_{15} \mathrm{GGBS}_{85}, \mathrm{~A}_{25} \mathrm{GGBS}_{75}$ can have a relatively high degree of hydration and is likely to form a well-structured silicate-aluminate network due to the high activator content used. Thus, the water in $\mathrm{A}_{25} \mathrm{GGBS}_{75}$ is likely to manifest itself in the form of chemically bound water instead of free water, which prevents fast drying shrinkage and mass loss. This means that the very high shrinkage values obtained are not only correlated with water loss. They might come from endogenous shrinkage as announced by Melo Neto et al. [25]. These results are in contradiction with the results of Chen et al. [63] who found that shrinkage of pure GGBS AAMs increased with higher doses of activator (and GGBS fineness). 
Adding FA to pure GGBS AAMs reduced the shrinkage slightly, although mass loss increased (the shrinkage was $3.6 \%$ and $1.8 \%$, and mass loss was $11.5 \%$ and $8.8 \%$ for $\mathrm{A}_{15} \mathrm{GGBS}_{42.5} \mathrm{FA}_{42.5}$ and $\mathrm{A}_{25} \mathrm{GGBS}_{37.5} \mathrm{FA}_{37.5}$, respectively, at 28 days). Gao et al. [44] also obtained the lowest shrinkage value for GGBS-FA mortars with the highest FA content. This could stem from a different pore-size distribution. Lee et al. [43] found similar results on GGBS-FA paste and mortar and attributed the high shrinkage values, observed when the proportion of GGBS was high, to high autogenous shrinkage. The highest shrinkage values were obtained for low activation rate $(\geq 1.8 \%$ at 2 days; $\geq 3.6 \%$ at 28 days). Whatever the proportion employed, GGBS-FA shrinkage remained high ( $\geq 1.8 \%$ at 28 days). This is a serious handicap for building applications when it is applied in practice.

Interesting evolution of shrinkage in the MK-GGBS AAMs is presented in Figure $7((\mathrm{~g})$, (h) and (i)). After 2 days, pure $\mathrm{MK}$ and pure GGBS shrinkage were 1.2\% $\left(\mathrm{A}_{15} \mathrm{MK}_{85}\right)$ and $2.4 \%\left(\mathrm{~A}_{15} \mathrm{GGBS}_{85}\right)$. At 28 days, shrinkage values reached 1.3 and $4.3 \%$ for $\mathrm{A}_{15} \mathrm{MK}_{85}$ and $\mathrm{A}_{15} \mathrm{GGBS}_{85}$ respectively. After 28 days, the samples $\mathrm{A}_{15} \mathrm{MK}_{72.5} \mathrm{GGBS}_{12.5}$ and $\mathrm{A}_{15} \mathrm{MK}_{61} \mathrm{GGBS}_{24}$ presented very low shrinkage (0.5\%) compared to pure MK or pure GGBS and the other AAMs studied.

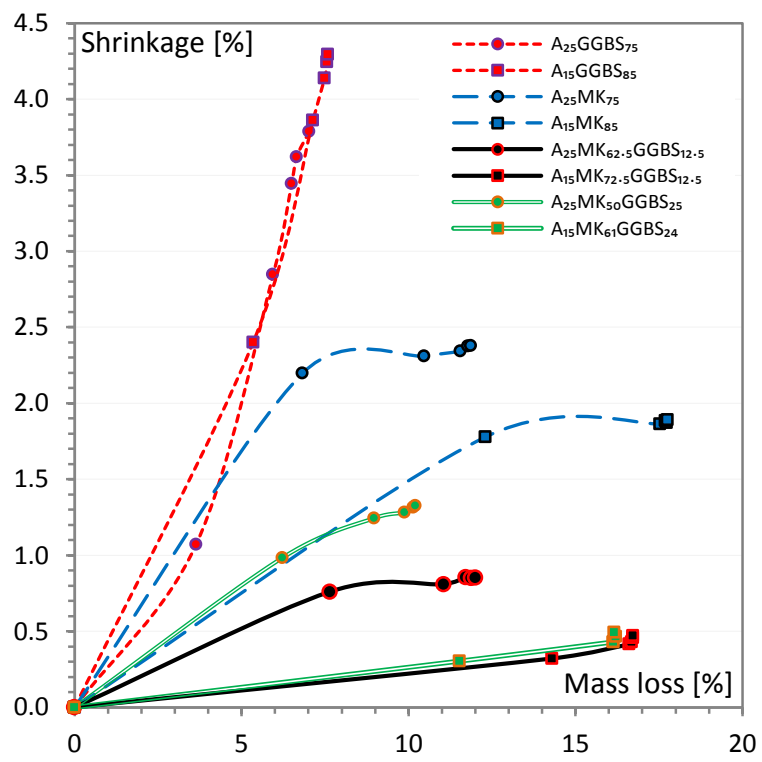

Figure 9. Shrinkage versus mass loss (circle: high activation rate; square: low activation rate).

To understand the differences between pure MK, pure GGBS and blended MK-GGBS AAMs regarding the relationship between shrinkage and mass loss, Figure 9 presents the shrinkage and mass loss evolution at 2, 7, 14, 21 and 28 days (Table 4). For pure GGBS, however low or high the activation is, the shrinkage shows a similar increasing trend with mass loss. However, for pure MK, the increasing rate of 
shrinkage vs mass loss is totally different between low and high activations. For high activation $\mathrm{A}_{25} \mathrm{MK}_{75}$, the shrinkage is higher than that for low activation $\mathrm{A}_{15} \mathrm{MK}_{85}$ when the same level of mass loss is taken into account. The excessive shrinkage of $\mathrm{A}_{25} \mathrm{MK}_{75}$ compared to $\mathrm{A}_{15} \mathrm{MK}_{85}$ can be attributed to autogenous shrinkage.

It is surprising to see that some compositions mixing MK and GGBS have lower shrinkage values than values obtained with these precursors alone. At low activation rate, $\mathrm{A}_{15} \mathrm{MK}_{85}$ and $\mathrm{A}_{15} \mathrm{GGBS}_{85}$ initial setting times are 265 and 45 minutes respectively. Thus, in $\mathrm{A}_{15} \mathrm{MK}_{72.5} \mathrm{GGBS}_{12.5}$, between 45 and 265 minutes, the C-A-S-H solid phase would appear in the paste as N-A-S-H solid phase appear more than 2 hours later. In these systems, both type of reaction products C-A-S-H from GGBS and N-A-S-H from the metakaolin are able to coexist [47]. As GGBS content is quite small compared to MK content, these particles would act as solid aggregates (discontinuous phase) that restrain the strong shrinkage caused by mass loss and explain the low shrinkage value obtained $(0.5 \%$ at 28 days). If the GGBS content is increased $\left(\mathrm{A}_{15} \mathrm{MK}_{61} \mathrm{GGBS}_{24}\right)$ the shrinkage does not evolve $(0.5 \%$ at 28 days $)$ because the GGBS content remains small compared to MK. However if the GGBS content becomes equal to or greater than the MK content, shrinkage increases, probably because GGBS quickly creates a continuous solid skeleton in which the lower $\mathrm{Ca} \mathrm{N}-\mathrm{A}-\mathrm{S}-\mathrm{H}$ phase is included $\left(1.1 \%\right.$ and $2.5 \%$ for $\mathrm{A}_{15} \mathrm{MK}_{42.5} \mathrm{GGBS}_{42.5}$ and $\mathrm{A}_{15} \mathrm{MK}_{61} \mathrm{GGBS}_{24}$ respectively). A similar evolution is observed at higher activation rate and the shrinkage values reached are always higher than the values obtained for low activation rate. As observed for mass loss, the highest shrinkage relative standard deviation is observed at 2 days $(3.3 \%$ - Table 4 - last line). The shrinkage average relative standard deviation remains small, revealing good repeatability of the shrinkage measurements.

Shrinkage is a major issue for AAMs [18,25]. The shrinkage results presented were obtained under severe shrinkage conditions. However, some interesting results were found by changing the proportions of the raw materials. To prevent shrinkage on MK-FA samples, low activation and low FA content is advised. GGBS-FA AAMs present high shrinkage, especially if the amount of GGBS is high. The association of the right proportions of GGBS and MK can significantly reduce the shrinkage problems encountered with pure MK [18] or pure GGBS AAMs [27]. Furthermore, protecting the samples from fast water loss for a few days would probably have led to much lower shrinkage values (especially for MK samples). 


\subsection{Compressive strength}

The compressive strengths of the 26 mixes made are presented in Figure 9. Tests were carried out after unmoulding (1 day), 7 and 28 days. After 1 day, MK-FA samples presented a wide range of compressive strength values (Figure 9 (a)). The lowest values were obtained for the highest FA content $\left(R_{c}=3.7 \mathrm{MPa}\right.$ for $\mathrm{A}_{25} \mathrm{MK}_{37.5} \mathrm{FA}_{37.5}$ and $\mathrm{R}_{\mathrm{c}}=1.2 \mathrm{MPa}$ for $\mathrm{A}_{15} \mathrm{MK}_{42.5} \mathrm{FA}_{42.5}$ ) which corresponds to the lower $\mathrm{SiO}_{2} / \mathrm{Na}_{2} \mathrm{O}$ ratio. High FA substitution tends to reduce the early strength development of MK-FA AAMs. At 1 day, the highest compressive strength values were obtained for high activation rates with pure MK and small FA substitution $\left(\mathrm{R}_{\mathrm{c}}=21.4 \mathrm{MPa}\right.$ for $\mathrm{A}_{25} \mathrm{MK}_{75}$ and $\mathrm{R}_{\mathrm{c}}=22.0 \mathrm{MPa}$ for $\left.\mathrm{A}_{25} \mathrm{MK}_{62.5} \mathrm{FA}_{12.5}\right)$. The fact that the compressive strength of $\mathrm{A}_{25} \mathrm{MK}_{62.5} \mathrm{FA}_{12.5}$ was similar to that of $\mathrm{A}_{25} \mathrm{MK}_{75}$ may be explained by better packing of the particles because of their different shapes. Whatever the FA substitution, low activation rate led to low 1 day compressive strength, $\mathrm{R}_{\mathrm{c}} \leq 5.6 \mathrm{MPa}$ (Figure 4 (b)). At 7 days, all compressive strengths increased significantly (Figure 9 (b)). The highest value was still obtained by $\mathrm{A}_{25} \mathrm{MK}_{62.5} \mathrm{FA}_{12.5}\left(\mathrm{R}_{\mathrm{c}}=52.0 \mathrm{MPa}\right)$. This is in agreement with the results of Duan et al. [64]. Between 7 and 28 days, the compressive strength did not evolve to any great extent (+ 2.6 MPa on average), which means that the degree of reaction of MK was already significant at 7 days. 


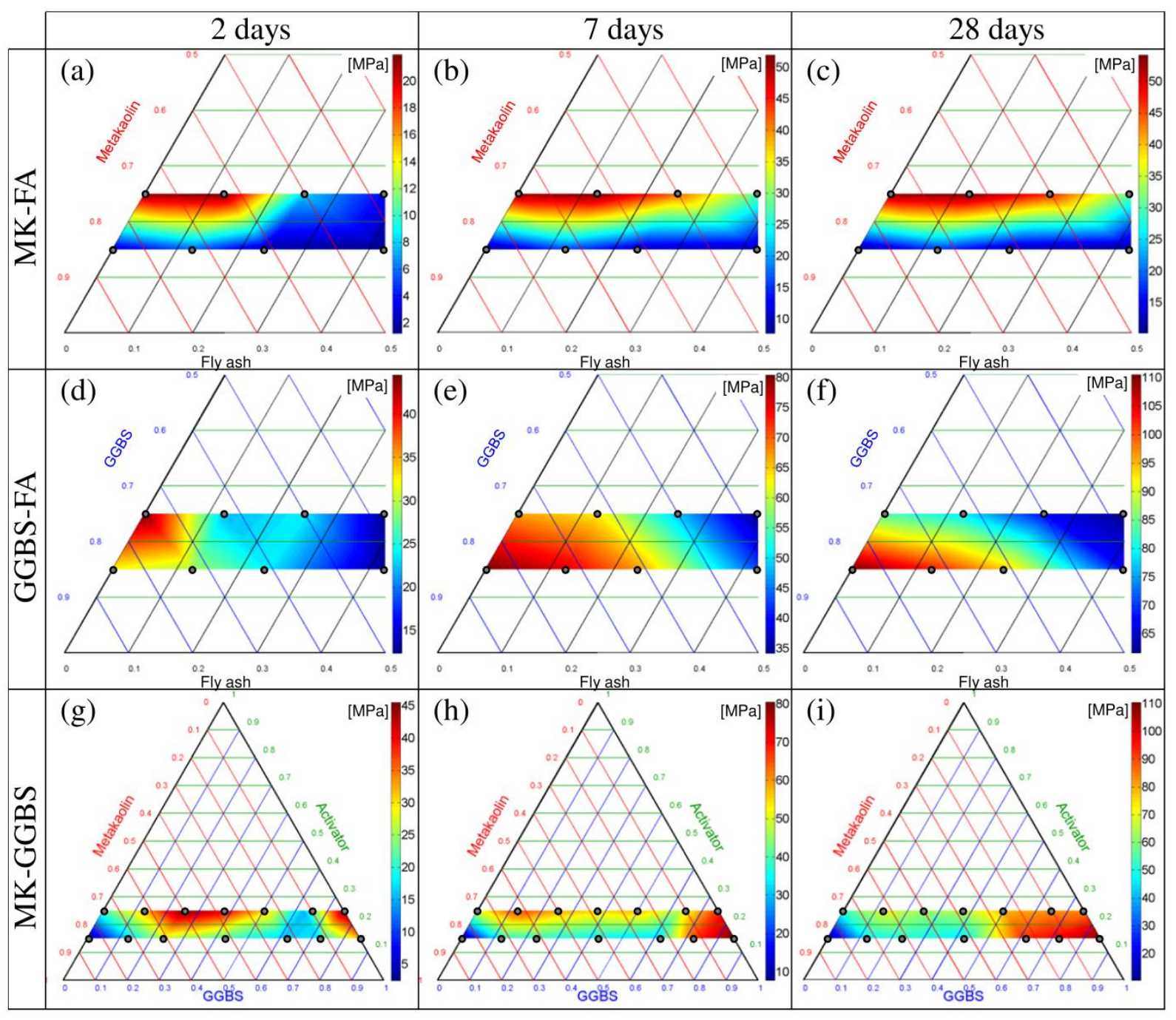

Figure 10. Compressive strength.

The compressive strength evolution of GGBS-FA mixes showed significant differences (Figure 9 (d), (e) and (f)). At 1 day (Figure 9 (d)), the highest compressive strength was obtained with $\mathrm{A}_{25} \mathrm{GGBS}_{75}$ $\left(\mathrm{R}_{\mathrm{c}}=52.0 \mathrm{MPa}\right)$. In a medium that was highly alkaline, because of high the Ca content, a strong C-A-S-H structure appeared quickly, leading to this fairly high compressive strength after 1 day. As observed for MK-FA, adding FA was detrimental to compressive strength because of its low activity. After 7 days (Figure $9(\mathrm{e})$ ), the pure GGBS sample with the low activator content $\left(\mathrm{A}_{15} \mathrm{GGBS}_{85}\right)$ had reached the highest compressive strength $\left(\mathrm{R}_{\mathrm{c}}=80.4 \mathrm{MPa}\right)$. At 28 days, this sample still had the highest compressive strength $\left(\mathrm{R}_{\mathrm{c}}=110.5 \mathrm{MPa}\right)$. A lower activator content was preferable to dissolve more GGBS and enhance the long-term reaction.

In FA systems, replacing MK by GGBS had a very positive effect on the compressive strength and, at 28 days, the lowest GGBS-FA compressive strength was $61.6 \mathrm{MPa}\left(\mathrm{A}_{25} \mathrm{GGBS}_{37.5} \mathrm{FA}_{37.5}\right)$ while it was 10.2 MPa for MK-FA $\left(\mathrm{A}_{15} \mathrm{MK}_{42.5} \mathrm{FA}_{42.5}\right)$. However, FA still had a negative effect on compressive strength 
because of its low reactivity [38]. A significant development of the compressive strength (+ $23 \mathrm{MPa}$ on average) was also observed between 7 and 28 days, meaning that the high pH provided by the $\mathrm{Ca}$ promoted a long-term reaction that could dissolve FA particles, enabling them to contribute to the strength gain, contrary to what was observed for MK-FA AAMs. The negative effect of FA on the compressive strength of GGBS-FA AAMs is also highlighted in $[41,44]$. GGBS grains are very fine (Table 2) and this physical characteristic could also explain the good mechanical performance observed.

The evolution of MK-GGBS compressive strength is presented in Figure $9((\mathrm{~g})$, (h) and (i)). Interesting compressive strength values are observed at 1 day for some MK-GGBS blends when GGBS content is lower than or equal to the MK content. The compressive strengths are 45.5 and $41.0 \mathrm{MPa}$ for $\mathrm{A}_{25} \mathrm{MK}_{50} \mathrm{GGBS}_{25}$ and $\mathrm{A}_{25} \mathrm{MK}_{37.5} \mathrm{GGBS}_{37.5}$, respectively. These values are higher than for the pure MK sample $\mathrm{A}_{25} \mathrm{MK}_{50}(21.4 \mathrm{MPa})$, but also higher than values obtained with higher GGBS substitution rates $\left(R_{c}=31.6\right.$ and $15.5 \mathrm{MPa}$ for $\mathrm{A}_{25} \mathrm{MK}_{25} \mathrm{GGBS}_{50}$ and $\mathrm{A}_{25} \mathrm{MK}_{12.5} \mathrm{GGBS}_{62.5}$, respectively). This good compatibility between MK and GGBS, already observed regarding shrinkage results, may be associated with good interactions between C-A-S-H and N-A-S-H gels. At 7 and 28 days the effect was less marked in (h) and (i) because of the high compressive strength obtained by pure GGBS AAMs. The compressive strength average relative standard deviations were higher than those observed for mass loss and shrinkage, with values of $8.7,12.2$ and $11.7 \%$ for 1,7 and 28 days, respectively. Due to the relatively small size of the specimens, there was a higher dispersion in the compressive strength results, which explains why the measurements were performed on eight specimens at each term. 


\begin{tabular}{|c|c|c|c|c|c|c|c|c|c|c|c|c|c|c|c|c|c|c|c|c|c|c|c|c|}
\hline & \multicolumn{4}{|c|}{ Ternary composition } & \multicolumn{6}{|c|}{ Molar ratio } & \multirow{2}{*}{$\begin{array}{c}\begin{array}{c}\text { Initial } \\
\text { setting } \\
\text { time }\end{array} \\
T s \\
\end{array}$} & \multicolumn{5}{|c|}{ Shrinkage } & \multicolumn{5}{|c|}{ Mass loss } & \multicolumn{3}{|c|}{$\begin{array}{l}\text { Compressive } \\
\text { strength }\end{array}$} \\
\hline & Activator & MK & FA & GGBS & $\mathrm{SiO}_{2} / \mathrm{Al}_{2} \mathrm{O}_{3}$ & $\mathrm{SiO}_{2} / \mathrm{Na}_{2} \mathrm{O}$ & $\mathrm{Na}_{2} \mathrm{O} / \mathrm{Al}_{2} \mathrm{O}_{3}$ & $\mathrm{H}_{2} \mathrm{O} / \mathrm{Na}_{2} \mathrm{O}$ & $\mathrm{CaO} / \mathrm{Al}_{2} \mathrm{O}_{3}$ & $\mathrm{CaO} / \mathrm{SiO}_{2}$ & & & & $\Delta \mathrm{l} / \mathrm{l}_{0}$ & & & & & $\Delta \mathrm{m} / \mathrm{m}_{0}$ & & & & $\mathrm{Rc}$ & \\
\hline Unit & $\%$ & $\%$ & $\%$ & $\%$ & & & - & & & & $\operatorname{mins}$ & & & $\%$ & & & & & $\%$ & & & & $\mathrm{MPa}$ & \\
\hline Time [days] & & & & & & & - & & & & & 2 & 7 & 14 & 21 & 28 & 2 & 7 & 14 & 21 & 28 & 1 & 7 & 28 \\
\hline $\mathrm{A}_{25} \mathrm{MK}_{62.5} \mathrm{FA}_{12 \cdot 5}$ & 62.5 & 12.5 & 25 & 0 & 3.83 & 3.91 & 0.98 & 12.43 & 0.04 & 0.01 & 380 & 2.1 & 2.2 & 2.3 & 2.3 & 2.3 & 6.5 & 11.5 & 12.0 & 12.0 & 12.1 & 22.0 & 52.0 & 54.2 \\
\hline $\mathrm{A}_{25} \mathrm{MK}_{50} \mathrm{FA}_{25}$ & 25.0 & 50.0 & 25.0 & 0.0 & 4.25 & 3.99 & 1.06 & 12.35 & 0.06 & 0.01 & 550 & 1.5 & 2.6 & 2.7 & 2.7 & 2.7 & 5.0 & 11.0 & 11.7 & 11.7 & 11.7 & 7.8 & 41.6 & 46.7 \\
\hline $\mathrm{A}_{25} \mathrm{MK}_{37.5} \mathrm{FA}_{37.5}$ & 25.0 & 37.5 & 37.5 & 0.0 & 4.75 & 4.08 & 1.17 & 12.27 & 0.09 & 0.02 & 750 & 1.4 & 3.2 & 3.3 & 3.3 & 3.4 & 3.8 & 10.8 & 11.5 & 11.5 & 11.5 & 3.7 & 28.1 & 30.8 \\
\hline $\mathrm{A}_{15} \mathrm{MK}_{72 \cdot 5} \mathrm{FA}_{12 \cdot 5}$ & 15.0 & 72.5 & 12.5 & 0.0 & 3.07 & 5.93 & 0.52 & 20.52 & 0.03 & 0.01 & 260 & 1.0 & 1.1 & 1.1 & 1.1 & 1.2 & 11.8 & 17.6 & 17.7 & 17.7 & 17.8 & 5.6 & 15.9 & 17.5 \\
\hline $\mathrm{A}_{15} \mathrm{MK}_{61} \mathrm{FA}_{24}$ & 15.0 & 61.0 & 24.0 & 0.0 & 3.36 & 6.03 & 0.56 & 20.32 & 0.05 & 0.02 & 475 & 1.1 & 1.2 & 1.2 & 1.2 & 1.2 & 10.3 & 17.2 & 17.3 & 17.4 & 17.4 & 1.9 & 10.1 & 12.0 \\
\hline $\mathrm{A}_{15} \mathrm{MK}_{42 \cdot 5} \mathrm{FA}_{42.5}$ & 15.0 & 42.5 & 42.5 & 0.0 & 3.91 & 6.20 & 0.63 & 20.01 & 0.09 & 0.02 & 480 & 1.2 & 1.3 & 1.3 & 1.3 & 1.3 & 11.0 & 17.1 & 11.5 & 17.4 & 17.4 & 1.2 & 9.3 & 10.2 \\
\hline $\mathrm{A}_{25} \mathrm{MK}_{75}$ & 25.0 & 75.0 & 0.0 & 0.0 & 3.46 & 3.83 & 0.90 & 12.52 & 0.02 & 0.00 & 360 & 2.2 & 2.3 & 2.3 & 2.4 & 2.4 & 6.8 & 10.5 & 11.6 & 11.8 & 11.9 & 21.4 & 50.5 & 53.2 \\
\hline $\mathrm{A}_{15} \mathrm{MK}_{85}$ & 15.0 & 85.0 & 0.0 & 0.0 & 2.80 & 5.81 & 0.48 & 20.75 & 0.02 & 0.01 & 265 & 1.2 & 1.2 & 1.2 & 1.3 & 1.3 & 12.3 & 17.5 & 17.7 & 17.7 & 17.8 & 2.5 & 7.7 & 10.4 \\
\hline $\mathrm{A}_{25} \mathrm{MK}_{62.5} \mathrm{GGBS}_{12.5}$ & 25.0 & 62.5 & 0.0 & 12.5 & 3.90 & 4.04 & 0.99 & 12.53 & 0.62 & 0.16 & 300 & 0.8 & 0.8 & 0.9 & 0.8 & 0.9 & 7.6 & 11.1 & 11.7 & 11.9 & 12.0 & 31.6 & 66.5 & 69.8 \\
\hline $\mathrm{A}_{25} \mathrm{MK}_{50} \mathrm{GGBS}_{25}$ & 25.0 & 50.0 & 0.0 & 25.0 & 4.44 & 4.05 & 1.10 & 12.54 & 1.36 & 0.31 & 160 & 1.0 & 1.2 & 1.3 & 1.3 & 1.3 & 6.2 & 9.0 & 9.9 & 10.2 & 10.2 & 45.5 & 58.6 & 62.7 \\
\hline $\mathrm{A}_{25} \mathrm{MK}_{37.5} \mathrm{GGBS}_{37.5}$ & 25.0 & 37.5 & 0.0 & 37.5 & 5.11 & 4.16 & 1.23 & 12.55 & 2.27 & 0.44 & 115 & 1.0 & 1.7 & 1.7 & 1.9 & 1.9 & 5.4 & 8.3 & 9.0 & 9.3 & 9.6 & 41.0 & 55.3 & 65.3 \\
\hline $\mathrm{A}_{25} \mathrm{MK}_{25} \mathrm{GGBS}_{50}$ & 25.0 & 25.0 & 0.0 & 50.0 & 5.95 & 4.28 & 1.39 & 12.57 & 3.43 & 0.58 & 90 & 1.1 & 2.5 & 2.9 & 3.0 & 3.1 & 4.7 & 7.7 & 8.5 & 8.8 & 9.1 & 31.6 & 57.6 & 79.3 \\
\hline $\mathrm{A}_{25} \mathrm{MK}_{12 \cdot 5} \mathrm{GGBS}_{62 \cdot 5}$ & 25.0 & 12.5 & 0.0 & 62.5 & 7.07 & 4.39 & 1.61 & 12.58 & 4.96 & 0.70 & 105 & 1.3 & 3.3 & 3.7 & 3.8 & 3.8 & 4.3 & 7.3 & 7.9 & 8.3 & 8.3 & 15.5 & 47.6 & 82.3 \\
\hline $\mathrm{A}_{15} \mathrm{MK}_{72 \cdot 5} \mathrm{GGBS}_{12 \cdot 5}$ & 15.0 & 72.5 & 0.0 & 12.5 & 3.13 & 6.00 & 0.52 & 20.78 & 0.54 & 0.17 & 115 & 0.3 & 0.4 & 0.4 & 0.5 & 0.5 & 14.3 & 16.6 & 16.7 & 16.7 & 16.7 & 16.4 & 36.9 & 47.1 \\
\hline $\mathrm{A}_{15} \mathrm{MK}_{61} \mathrm{GGBS}_{24}$ & 15.0 & 61.0 & 0.0 & 24.0 & 3.48 & 6.17 & 0.56 & 20.81 & 1.12 & 0.32 & 65 & 0.3 & 0.4 & 0.4 & 0.5 & 0.5 & 11.5 & 16.1 & 16.1 & 16.2 & 16.2 & 26.8 & 38.2 & 50.8 \\
\hline $\mathrm{A}_{15} \mathrm{MK}_{42.5} \mathrm{GGBS}_{42.5}$ & 15.0 & 42.5 & 0.0 & 42.5 & 4.20 & 6.45 & 0.65 & 20.87 & 2.27 & 0.54 & 50 & 0.9 & 1.0 & 2.6 & 1.1 & 1.1 & 11.7 & 15.6 & 15.7 & 15.7 & 15.7 & 21.7 & 34.0 & 46.3 \\
\hline $\mathrm{A}_{15} \mathrm{MK}_{24} \mathrm{GGBS}_{61}$ & 15.0 & 24.0 & 0.0 & 61.0 & 5.19 & 6.74 & 0.77 & 20.92 & 3.85 & 0.74 & 40 & 2.0 & 2.3 & 2.4 & 2.4 & 2.5 & 7.9 & 13.0 & 13.8 & 14.1 & 14.1 & 16.0 & 31.5 & 92.8 \\
\hline $\mathrm{A}_{15} \mathrm{MK}_{12.5} \mathrm{GGBS}_{72.5}$ & 15.0 & 12.5 & 0.0 & 72.5 & 6.91 & 6.91 & 0.87 & 20.95 & 5.17 & 0.86 & 40 & 3.1 & 3.9 & 4.1 & 4.2 & 4.2 & 6.9 & 9.7 & 10.6 & 10.7 & 10.8 & 17.9 & 66.5 & 98.6 \\
\hline $\mathrm{A}_{25} \mathrm{GGBS}_{75}$ & 25.0 & 0.0 & 0.0 & 75.0 & 8.60 & 4.50 & 1.91 & 12.59 & 7.06 & 0.82 & 70 & 1.1 & 2.8 & 3.4 & 3.6 & 3.8 & 3.6 & 5.9 & 6.5 & 6.6 & 7.0 & 44.5 & 67.3 & 83.7 \\
\hline $\mathrm{A}_{15} \mathrm{GGBS}_{85}$ & 15.0 & 0.0 & 0.0 & 85.0 & 7.19 & 7.10 & 1.01 & 20.99 & 7.06 & 0.98 & 45 & 2.4 & 3.9 & 4.1 & 4.2 & 4.3 & 5.3 & 7.1 & 7.5 & 7.6 & 7.6 & 32.2 & 80.4 & 110.5 \\
\hline $\mathrm{A}_{15} \mathrm{GGBS}_{72 \cdot 5} \mathrm{FA}_{12 \cdot 5}$ & 15.0 & 0.0 & 12.5 & 72.5 & 6.53 & 7.09 & 0.92 & 20.68 & 5.49 & 0.84 & 45 & 2.2 & 3.5 & 3.8 & 3.9 & 3.9 & 5.5 & 7.4 & 7.7 & 7.8 & 7.8 & 29.5 & 75.7 & 103.1 \\
\hline $\mathrm{A}_{25} \mathrm{GGBS}_{62 \cdot 5} \mathrm{FA}_{12 \cdot 5}$ & 25.0 & 0.0 & 12.5 & 62.5 & 7.70 & 4.52 & 1.70 & 12.48 & 5.30 & 0.69 & 110 & 1.1 & 2.9 & 3.3 & 3.3 & 3.4 & 3.8 & 6.2 & 6.8 & 7.0 & 7.1 & 22.1 & 63.4 & 78.9 \\
\hline $\mathrm{A}_{25} \mathrm{GGBS}_{50} \mathrm{FA}_{25}$ & 25.0 & 0.0 & 25.0 & 50.0 & 6.98 & 4.53 & 1.54 & 12.37 & 3.91 & 0.56 & 145 & 0.9 & 2.2 & 2.3 & 2.3 & 2.3 & 4.0 & 7.1 & 7.7 & 7.9 & 8.0 & 23.8 & 48.6 & 67.5 \\
\hline $\mathrm{A}_{25} \mathrm{GGBS}_{37.5} \mathrm{FA}_{37.5}$ & 25.0 & 0.0 & 37.5 & 37.5 & 6.41 & 4.55 & 1.41 & 12.27 & 2.77 & 0.43 & 230 & 0.8 & 1.7 & 1.8 & 1.8 & 1.8 & 3.9 & 7.8 & 8.7 & 8.7 & 8.8 & 12.8 & 34.2 & 61.6 \\
\hline $\mathrm{A}_{15} \mathrm{GGBS}_{61} \mathrm{FA}_{24}$ & 15.0 & 0.0 & 24.0 & 61.0 & 6.03 & 7.08 & 0.85 & 20.41 & 4.30 & 0.71 & 50 & 2.0 & 3.4 & 3.6 & 3.7 & 3.8 & 5.9 & 8.6 & 10.5 & 9.1 & 9.4 & 24.0 & 67.2 & 94.3 \\
\hline $\mathrm{A}_{15} \mathrm{GGBS}_{42 \cdot 5} \mathrm{FA}_{42 \cdot 5}$ & 15.0 & 0.0 & 42.5 & 42.5 & 5.39 & 7.07 & 0.76 & 19.98 & 2.77 & 0.51 & 60 & 2.1 & 3.3 & 3.5 & 3.6 & 3.6 & 6.5 & 10.5 & 11.1 & 11.3 & 11.5 & 12.4 & 42.8 & 67.5 \\
\hline & & & & & & & & & & & $\begin{array}{c}\text { Relative } \\
\text { average } \\
\text { standard } \\
\text { deviation } \\
{[\%]}\end{array}$ & 3.8 & 3.1 & 2.5 & 2.1 & 2.2 & 3.3 & 1.6 & 1.0 & 1.0 & 1.2 & 8.7 & 12.2 & 11.9 \\
\hline
\end{tabular}




\section{Discussion}

This discussion part and associated summary table (Table 5) aim to summarize all the information presented in this article and to guide the formulation of blended AAMs depending on the users' needs. On-site, it is important to mastered initial setting time and FA can be used as a retarder for both MK and GGBS AAM. For pure MK, initial setting lied between 360 and 235 minutes which can be long enough for on-site production. However, pure GGBS AAMs presented very short initial setting time (70 and 45 minutes for $\mathrm{A}_{25} \mathrm{GGBS}_{75}$ and $\mathrm{A}_{15} \mathrm{GGBS}_{85}$ respectively) which can cause problems on-site. Using FA to mastered initial setting time seemed appropriate as it reduce the $\mathrm{SiO}_{2} / \mathrm{Al}_{2} \mathrm{O}_{3}$ ratio. For MK-GGBS blends, MK content could also be adjusted to achieve to required initial setting time.

Mass loss is not a very important property for civil engineering applications. However, it is highly correlated to shrinkage for geopolymers (low Ca content, MK or FA). For geopolymers, mass loss strongly depended on activation rates. Increasing activator content (i.e. increasing $\mathrm{Na}_{2} \mathrm{O} / \mathrm{Al}_{2} \mathrm{O}_{3}$ ratio) reduced mass loss. When GGBS was employed, the reaction path was very different and a significant amount of water was chemically bonded, which explained why the mass loss was reduced with GGBS.

The literature and experimental results indicate that pure MK or pure GGBS AAMs suffer from shrinkage. Adding FA to MK had a positive impact on shrinkage after 2 days. However, at 28 days, the highest shrinkage values were obtained for the highest amount of FA and high alkali activation (higher $\mathrm{SiO}_{2} / \mathrm{Al}_{2} \mathrm{O}_{3}$ ratio). For GGBS-FA blends, FA addition interestingly reduced the shrinkage (for both activation rates). Finally, the experimental results revealed that if MK and GGBS were mixed in proper proportion, it significantly decreased the shrinkage problems encountered with pure MK [18] or pure GGBS AAMs [27].

Very different compressive strength results were achieved. The experiments showed that adding small FA content (12.5\%) to MK AAMs did not modify the compressive strength for high activation rate and it increased the compressive strength for low activation rate. However, FA content must be kept below or equal to $12.5 \%$, otherwise compressive strength decreased. Nonetheless, acceptable compressive strength was still achieved for high activation rate and high FA content (30.8 $\mathrm{MPa}$ for $\mathrm{A}_{25} \mathrm{MK}_{37.5} \mathrm{FA}_{37.5}$ at 28 days). Compared to MK-FA, GGBS-FA systems reached higher compressive strength. As observed for MK-FA blends, FA tended to decrease the compressive strength value but could be required to achieve longer initial setting time as indicated above. Unlike MK-FA AAMs, the higher compressive strength 
were obtained at low activation rate which was very interesting because alkaline solution was the most expensive component of these AAMs. Finally, at 28 days, MK-GGBS blends compressive strength were between those of pure MK and pure GGBS AAMs. However, very high early strength were observed for MK-GGBS blends if the GGBS content was below or equal to MK (1 day - 45.5 and 41.0 MPa for $\mathrm{A}_{25} \mathrm{MK}_{50} \mathrm{GGBS}_{25}$ and $\mathrm{A}_{25} \mathrm{MK}_{37.5} \mathrm{GGBS}_{37.5}$, respectively). It corresponded to the MK-GGBS blends that also achieved very low shrinkage.

Table 5. Summary of the main results of pure and blended AAMs.

\begin{tabular}{|c|c|c|c|c|}
\hline Precursor(s) & Initial setting time & Mass loss & Shrinkage & Compressive strength \\
\hline MK & $\begin{array}{l}\text { Increase with } \\
\mathrm{SiO}_{2} / \mathrm{Al}_{2} \mathrm{O}_{3} \text { ratio }\end{array}$ & $\begin{array}{l}\text { Decrease when } \\
\text { activator } \\
\text { content is } \\
\text { increased (i.e. } \\
\text { when } \\
\mathrm{Na}_{2} \mathrm{O} / \mathrm{Al}_{2} \mathrm{O}_{3} \\
\text { increase) }\end{array}$ & High & $\begin{array}{l}\text { Good. Increase with } \\
\text { activation rate }\end{array}$ \\
\hline FA & \multicolumn{4}{|c|}{$\begin{array}{c}\text { Pure FA AAMs were not tested due to the lack of FA reactivity under ambient temperature. } \\
\text { Most of the pure FA AAMs presented on literature are thermally treated to achieve } \\
\text { reasonable compressive strength. }\end{array}$} \\
\hline GGBS & $\begin{array}{c}\text { Short due to } \mathrm{Ca} \\
\text { presence }\end{array}$ & $\begin{array}{l}\text { Small due to C- } \\
\text { A-S-H } \\
\text { formation }\end{array}$ & High & $\begin{array}{l}\text { High compressive } \\
\text { strength. Highest } 28 \text { days } \\
\text { compressive strength } \\
\text { obtained for low } \\
\text { activation rate }\end{array}$ \\
\hline MK-FA & $\begin{array}{l}\text { Increase with FA } \\
\text { content }\end{array}$ & $\begin{array}{l}\text { Increase with } \\
\text { FA content }\end{array}$ & $\begin{array}{l}\text { High. } \\
\text { Adding FA increases } \\
\text { shrinkage. Shrinkage } \\
\text { also increases with } \\
\text { high activation rate }\end{array}$ & $\begin{array}{l}\text { When FA content exceeds } \\
12 \% \text {, compressive } \\
\text { strength strongly } \\
\text { decreased. }\end{array}$ \\
\hline GGBS-FA & $\begin{array}{l}\text { Increase with FA } \\
\text { content but remain } \\
\text { smaller than MK- } \\
\text { FA blends }\end{array}$ & $\begin{array}{l}\text { Increase with } \\
\text { FA content but } \\
\text { remain smaller } \\
\text { than MK-FA } \\
\text { blends }\end{array}$ & $\begin{array}{l}\text { High FA content } \\
\text { significantly } \\
\text { decreases shrinkage, } \\
\text { especially at high } \\
\text { activation rate }\end{array}$ & $\begin{array}{c}\text { FA decreased } \\
\text { compressive strength }\end{array}$ \\
\hline MK-GGBS & $\begin{array}{c}\text { Increase with } \mathrm{MK} \\
\text { content }\end{array}$ & $\begin{array}{l}\text { Decrease with } \\
\text { GGBS and high } \\
\text { activation rate }\end{array}$ & $\begin{array}{l}\text { MK-GGBS blends } \\
\text { achieved lower } \\
\text { shrinkage than pure } \\
\text { MK or GGBS } \\
\text { AAMs }\end{array}$ & $\begin{array}{l}\text { High early strength } \\
\text { observed when GGBS } \\
\text { content is lower than or } \\
\text { equal to the MK content }\end{array}$ \\
\hline
\end{tabular}




\section{Conclusion}

The influence of several AAM compositions on the principal properties useful in civil engineering materials (initial setting time, shrinkage, mass loss, compressive strength) were investigated. All the tests were carried out at ambient temperature. Twenty-six different mixes were studied and have been presented using a ternary representation. The aim was to associate two different precursors (MK and FA, MK and GGBS, or FA and GGBS) in different proportions with two alkaline activator contents (15\% and $25 \%$ of dry extract of alkaline solution) and investigate the properties obtained in the samples. Some interesting findings were made:

- Pure MK AAMs present an intermediate initial setting time while Pure GGBS AAMs have fast initials setting time. The high Ca content of GGBS explains its very short initial setting time, which is due to fast production of C-A-S-H gel. FA can be used to delayed setting for both pure MK and GGBS AAMs.

- For geopolymer (low Ca content precursors), mass loss and shrinkage are highly related. Shrinkage is mainly due to drying. Pure GGBS AAMs shrinkage is mostly autogenous.

- The association of MK and GGBS, in the right proportions enable to significantly reduce shrinkage. Very low shrinkage values were found for MK-GGBS (with low GGBS content) compared to the other AAMs.

- Good mechanical performances were achieved by both MK and GGBS AAMs. Higher compressive strength value are obtained with high activation rate while he best values were observed for low activation rate for pure GGBS which is economically interesting given the high cost of the alkaline solution.

- High early compressive strength (up to 45.5 MPa at 1 day) was observed for MK-GGBS blends with high activator content and a relatively small proportion of GGBS (12.5 to 37.5\%).

A summary table was presented at the end of the discussion part. This article should help in the formulation of blended AAMs based on the association of two aluminosilicate precursors depending on the desired properties. 
[1] USGS Mineral Resources Program website, (n.d.). https://minerals.usgs.gov/ (accessed February 7, 2017).

[2] F. Pacheco-Torgal, Z. Abdollahnejad, A.F. Camões, M. Jamshidi, Y. Ding, Durability of alkali-activated binders: A clear advantage over Portland cement or an unproven issue?, Constr. Build. Mater. 30 (2012) 400-405. doi:10.1016/j.conbuildmat.2011.12.017.

[3] J.L. Provis, A. Palomo, C. Shi, Advances in understanding alkali-activated materials, Cem. Concr. Res. 78, Part A (2015) 110-125. doi:10.1016/j.cemconres.2015.04.013.

[4] P. Duxson, A. Fernández-Jiménez, J.L. Provis, G.C. Lukey, A. Palomo, J.S.J. van Deventer, Geopolymer technology: the current state of the art, J. Mater. Sci. 42 (2006) 2917-2933. doi:10.1007/s10853-006-0637-z.

[5] P. Duxson, J.L. Provis, G.C. Lukey, J.S.J. van Deventer, The role of inorganic polymer technology in the development of "green concrete," Cem. Concr. Res. 37 (2007) 15901597. doi:10.1016/j.cemconres.2007.08.018.

[6] D.L.Y. Kong, J.G. Sanjayan, Effect of elevated temperatures on geopolymer paste, mortar and concrete, Cem. Concr. Res. 40 (2010) 334-339. doi:10.1016/j.cemconres.2009.10.017.

[7] V. Vaou, D. Panias, Thermal insulating foamy geopolymers from perlite, Miner. Eng. 23 (2010) 1146-1151. doi:10.1016/j.mineng.2010.07.015.

[8] J. Temuujin, A. Minjigmaa, W. Rickard, M. Lee, I. Williams, A. van Riessen, Fly ash based geopolymer thin coatings on metal substrates and its thermal evaluation, J. Hazard. Mater. 180 (2010) 748-752. doi:10.1016/j.jhazmat.2010.04.121.

[9] J. Temuujin, W. Rickard, M. Lee, A. van Riessen, Preparation and thermal properties of fire resistant metakaolin-based geopolymer-type coatings, J. Non-Cryst. Solids. 357 (2011) 1399-1404. doi:10.1016/j.jnoncrysol.2010.09.063.

[10] A. Fernández-Jiménez, A. Palomo, D.E. Macphee, E.E. Lachowski, Fixing Arsenic in Alkali-Activated Cementitious Matrices, J. Am. Ceram. Soc. 88 (2005) 1122-1126. doi:10.1111/j.1551-2916.2005.00224.x.

[11] J.G.S. Van Jaarsveld, J.S.J. Van Deventer, L. Lorenzen, The potential use of geopolymeric materials to immobilise toxic metals: Part I. Theory and applications, Miner. Eng. 10 (1997) 659-669. doi:10.1016/S0892-6875(97)00046-0.

[12] J. Wang, J. Wang, Q. Zhang, Y. Li, Immobilization of simulated low and intermediate level waste in alkali-activated slag-fly ash-metakaolin hydroceramics, Nucl. Eng. Des. 300 (2016) 67-73. doi:10.1016/j.nucengdes.2016.01.011.

[13] K.J.D. Mackenzie, M. Welter, Geopolymer (aluminosilicate) composites: synthesis, properties and applications, in: Adv. Ceram. Matrix Compos., Elsevier, 2014: pp. 445470.

[14] C. Li, H. Sun, L. Li, A review: The comparison between alkali-activated slag ( $\mathrm{Si}+\mathrm{Ca})$ and metakaolin ( $\mathrm{Si}+\mathrm{Al})$ cements, Cem. Concr. Res. 40 (2010) 1341-1349.

[15] C. Shi, A.F. Jiménez, A. Palomo, New cements for the 21st century: The pursuit of an alternative to Portland cement, Cem. Concr. Res. 41 (2011) 750-763. doi:10.1016/j.cemconres.2011.03.016.

[16] X. Gao, Q.L. Yu, H.J.H. Brouwers, Properties of alkali activated slag-fly ash blends with limestone addition, Cem. Concr. Compos. 59 (2015) 119-128. doi:10.1016/j.cemconcomp.2015.01.007.

[17] B. Singh, G. Ishwarya, M. Gupta, S.K. Bhattacharyya, Geopolymer concrete: A review of some recent developments, Constr. Build. Mater. 85 (2015) 78-90. doi:10.1016/j.conbuildmat.2015.03.036.

[18] C. Kuenzel, L.J. Vandeperre, S. Donatello, A.R. Boccaccini, C. Cheeseman, Ambient Temperature Drying Shrinkage and Cracking in Metakaolin-Based Geopolymers, J. Am. Ceram. Soc. 95 (2012) 3270-3277. doi:10.1111/j.1551-2916.2012.05380.x.

[19] D.S. Perera, O. Uchida, E.R. Vance, K.S. Finnie, Influence of curing schedule on the integrity of geopolymers, J. Mater. Sci. 42 (2006) 3099-3106. doi:10.1007/s10853-0060533-6. 
[20] I. Ozer, S. Soyer-Uzun, Relations between the structural characteristics and compressive strength in metakaolin based geopolymers with different molar Si/Al ratios, Ceram. Int. 41 (2015) 10192-10198. doi:10.1016/j.ceramint.2015.04.125.

[21] F. Pacheco-Torgal, D. Moura, Y. Ding, S. Jalali, Composition, strength and workability of alkali-activated metakaolin based mortars, Constr. Build. Mater. 25 (2011) 3732-3745. doi:10.1016/j.conbuildmat.2011.04.017.

[22] R. Pouhet, M. Cyr, Formulation and performance of flash metakaolin geopolymer concretes, Constr. Build. Mater. 120 (2016) 150-160. doi:10.1016/j.conbuildmat.2016.05.061.

[23] S.A. Bernal, E.D. Rodríguez, R.M. de Gutiérrez, M. Gordillo, J.L. Provis, Mechanical and thermal characterisation of geopolymers based on silicate-activated metakaolin/slag blends, J. Mater. Sci. 46 (2011) 5477-5486. doi:10.1007/s10853-011-5490-z.

[24] R. Pouhet, Formulation and durability of metakaolin-based geopolymers, PhD Thesis, LMDC Toulouse, France, 2015.

[25] A.A. Melo Neto, M.A. Cincotto, W. Repette, Drying and autogenous shrinkage of pastes and mortars with activated slag cement, Cem. Concr. Res. 38 (2008) 565-574. doi:10.1016/j.cemconres.2007.11.002.

[26] A.R. Brough, A. Atkinson, Sodium silicate-based, alkali-activated slag mortars: Part I. Strength, hydration and microstructure, Cem. Concr. Res. 32 (2002) 865-879. doi:10.1016/S0008-8846(02)00717-2.

[27] C. Duran Atiş, C. Bilim, Ö. Çelik, O. Karahan, Influence of activator on the strength and drying shrinkage of alkali-activated slag mortar, Constr. Build. Mater. 23 (2009) 548-555. doi:10.1016/j.conbuildmat.2007.10.011.

[28] O. Burciaga-Díaz, R.X. Magallanes-Rivera, J.I. Escalante-García, Alkali-activated slagmetakaolin pastes: strength, structural, and microstructural characterization, J. Sustain. Cem.-Based Mater. 2 (2013) 111-127. doi:10.1080/21650373.2013.801799.

[29] M. Chi, J. Chang, R. Huang, Strength and Drying Shrinkage of Alkali-Activated Slag Paste and Mortar, Adv. Civ. Eng. 2012 (2012) e579732. doi:10.1155/2012/579732.

[30] X. Guo, H. Shi, W.A. Dick, Compressive strength and microstructural characteristics of class C fly ash geopolymer, Cem. Concr. Compos. 32 (2010) 142-147. doi:10.1016/j.cemconcomp.2009.11.003.

[31] P. Chindaprasirt, T. Chareerat, V. Sirivivatnanon, Workability and strength of coarse high calcium fly ash geopolymer, Cem. Concr. Compos. 29 (2007) 224-229. doi:10.1016/j.cemconcomp.2006.11.002.

[32] J. Temuujin, A. van Riessen, K.J.D. MacKenzie, Preparation and characterisation of fly ash based geopolymer mortars, Constr. Build. Mater. 24 (2010) 1906-1910. doi:10.1016/j.conbuildmat.2010.04.012.

[33] M. Soutsos, A.P. Boyle, R. Vinai, A. Hadjierakleous, S.J. Barnett, Factors influencing the compressive strength of fly ash based geopolymers, Constr. Build. Mater. 110 (2016) 355-368. doi:10.1016/j.conbuildmat.2015.11.045.

[34] P. Pavithra, M. Srinivasula Reddy, P. Dinakar, B. Hanumantha Rao, B.K. Satpathy, A.N. Mohanty, A mix design procedure for geopolymer concrete with fly ash, J. Clean. Prod. 133 (2016) 117-125. doi:10.1016/j.jclepro.2016.05.041.

[35] J.G.S. van Jaarsveld, J.S.J. van Deventer, G.C. Lukey, The effect of composition and temperature on the properties of fly ash- and kaolinite-based geopolymers, Chem. Eng. J. 89 (2002) 63-73. doi:10.1016/S1385-8947(02)00025-6.

[36] R. Rajamma, J.A. Labrincha, V.M. Ferreira, Alkali activation of biomass fly ashmetakaolin blends, Fuel. 98 (2012) 265-271. doi:10.1016/j.fuel.2012.04.006.

[37] M. Logesh Kumar, V. Revathi, Metakaolin bottom ash blend geopolymer mortar - A feasibility study, Constr. Build. Mater. 114 (2016) 1-5. doi:10.1016/j.conbuildmat.2016.03.149.

[38] S. Kumar, R. Kumar, S.P. Mehrotra, Influence of granulated blast furnace slag on the reaction, structure and properties of fly ash based geopolymer, J. Mater. Sci. 45 (2009) 607-615. doi:10.1007/s10853-009-3934-5. 
[39] S. Puligilla, P. Mondal, Role of slag in microstructural development and hardening of fly ash-slag geopolymer, Cem. Concr. Res. 43 (2013) 70-80. doi:10.1016/j.cemconres.2012.10.004.

[40] Y. Liu, W. Zhu, E.-H. Yang, Alkali-activated ground granulated blast-furnace slag incorporating incinerator fly ash as a potential binder, Constr. Build. Mater. 112 (2016) 1005-1012. doi:10.1016/j.conbuildmat.2016.02.153.

[41] X. Yao, T. Yang, Z. Zhang, Compressive strength development and shrinkage of alkaliactivated fly ash-slag blends associated with efflorescence, Mater. Struct. (2015) 1-12. doi:10.1617/s11527-015-0694-3.

[42] Z. Zhang, L. Li, X. Ma, H. Wang, Compositional, microstructural and mechanical properties of ambient condition cured alkali-activated cement, Constr. Build. Mater. 113 (2016) 237-245. doi:10.1016/j.conbuildmat.2016.03.043.

[43] N.K. Lee, J.G. Jang, H.K. Lee, Shrinkage characteristics of alkali-activated fly ash/slag paste and mortar at early ages, Cem. Concr. Compos. 53 (2014) 239-248. doi:10.1016/j.cemconcomp.2014.07.007.

[44] X. Gao, Q.L. Yu, H.J.H. Brouwers, Assessing the porosity and shrinkage of alkali activated slag-fly ash composites designed applying a packing model, Constr. Build. Mater. 119 (2016) 175-184. doi:10.1016/j.conbuildmat.2016.05.026.

[45] N.K. Lee, H.K. Lee, Setting and mechanical properties of alkali-activated fly ash/slag concrete manufactured at room temperature, Constr. Build. Mater. 47 (2013) 1201-1209. doi:10.1016/j.conbuildmat.2013.05.107.

[46] M.C. Bignozzi, S. Manzi, I. Lancellotti, E. Kamseu, L. Barbieri, C. Leonelli, Mix-design and characterization of alkali activated materials based on metakaolin and ladle slag, Appl. Clay Sci. 73 (2013) 78-85. doi:10.1016/j.clay.2012.09.015.

[47] A. Buchwald, H. Hilbig, C. Kaps, Alkali-activated metakaolin-slag blends-performance and structure in dependence of their composition, J. Mater. Sci. 42 (2007) 3024-3032. doi:10.1007/s10853-006-0525-6.

[48] S.A. Bernal, E.D. Rodríguez, R.M. de Gutiérrez, J.L. Provis, S. Delvasto, Activation of Metakaolin/Slag Blends Using Alkaline Solutions Based on Chemically Modified Silica Fume and Rice Husk Ash, Waste Biomass Valorization. 3 (2011) 99-108. doi:10.1007/s12649-011-9093-3.

[49] P.H.R. Borges, N. Banthia, H.A. Alcamand, W.L. Vasconcelos, E.H.M. Nunes, Performance of blended metakaolin/blastfurnace slag alkali-activated mortars, Cem. Concr. Compos. 71 (2016) 42-52. doi:10.1016/j.cemconcomp.2016.04.008.

[50] M. Cyr, R. Idir, T. Poinot, Properties of inorganic polymer (geopolymer) mortars made of glass cullet, J. Mater. Sci. 47 (2011) 2782-2797. doi:10.1007/s10853-011-6107-2.

[51] R. San Nicolas, M. Cyr, G. Escadeillas, Characteristics and applications of flash metakaolins, Appl. Clay Sci. 83-84 (2013) 253-262. doi:10.1016/j.clay.2013.08.036.

[52] R. San Nicolas, M. Cyr, G. Escadeillas, Performance-based approach to durability of concrete containing flash-calcined metakaolin as cement replacement, Constr. Build. Mater. 55 (2014) 313-322. doi:10.1016/j.conbuildmat.2014.01.063.

[53] M. Cyr, A. Tagnit-Hamou, Particle size distribution of fine powders by LASER diffraction spectrometry. Case of cementitious materials, Mater. Struct. 34 (2001) 342350. doi:10.1007/BF02486485.

[54] R.B. Jewell, R.F. Rathbone, Optical properties of coal combustion products for particlesize analysis by laser diffraction, Coal Combust. Gasif. Prod. (2009) 6.

[55] Z. Zuhua, Y. Xiao, Z. Huajun, C. Yue, Role of water in the synthesis of calcined kaolinbased geopolymer, Appl. Clay Sci. 43 (2009) 218-223. doi:10.1016/j.clay.2008.09.003.

[56] ASTM C191 - 01, ASTM C191 - 01 - Standard Test Method for Time of Setting of Hydraulic Cement by Vicat Needle, (2006).

[57] ASTM C596 - 09e1, ASTM C596 - 09e1 - Standard Test Method for Drying Shrinkage of Mortar Containing Hydraulic Cement, (2001).

[58] C.K. Yip, G.C. Lukey, J.S.J. van Deventer, The coexistence of geopolymeric gel and calcium silicate hydrate at the early stage of alkaline activation, Cem. Concr. Res. 35 (2005) 1688-1697. doi:10.1016/j.cemconres.2004.10.042. 
[59] K. Gao, K.-L. Lin, D. Wang, C.-L. Hwang, H.-S. Shiu, Y.-M. Chang, T.-W. Cheng, Effects $\mathrm{SiO} 2 / \mathrm{Na} 2 \mathrm{O}$ molar ratio on mechanical properties and the microstructure of nano$\mathrm{SiO} 2$ metakaolin-based geopolymers, Constr. Build. Mater. 53 (2014) 503-510. doi:10.1016/j.conbuildmat.2013.12.003.

[60] C.K. Yip, G.C. Lukey, J.L. Provis, J.S.J. van Deventer, Effect of calcium silicate sources on geopolymerisation, Cem. Concr. Res. 38 (2008) 554-564. doi:10.1016/j.cemconres.2007.11.001.

[61] S. Delair, É. Prud'homme, C. Peyratout, A. Smith, P. Michaud, L. Eloy, E. Joussein, S. Rossignol, Durability of inorganic foam in solution: The role of alkali elements in the geopolymer network, Corros. Sci. 59 (2012) 213-221. doi:10.1016/j.corsci.2012.03.002.

[62] I. Garcia-Lodeiro, A. Palomo, A. Fernández-Jiménez, D.E. Macphee, Compatibility studies between N-A-S-H and C-A-S-H gels. Study in the ternary diagram $\mathrm{Na} 2 \mathrm{O}-\mathrm{CaO}-$ Al2O3-SiO2-H2O, Cem. Concr. Res. $41 \quad$ (2011) 923-931. doi:10.1016/j.cemconres.2011.05.006.

[63] W. Chen, H.J.H. Brouwers, The hydration of slag, part 1: reaction models for alkaliactivated slag, J. Mater. Sci. 42 (2006) 428-443. doi:10.1007/s10853-006-0873-2.

[64] P. Duan, C. Yan, W. Zhou, Influence of partial replacement of fly ash by metakaolin on mechanical properties and microstructure of fly ash geopolymer paste exposed to sulfate attack, Ceram. Int. 42 (2016) 3504-3517. doi:10.1016/j.ceramint.2015.10.154. 